Biuletyn Historii Sztuki LXXXII:2020, nr 3

ISSN 00063967

Katarzyna Mikocka-Rachubowa

Warszawa, Instytut Sztuki PAN

https://orcid.org/0000-0001-7293-7490

\title{
Księcia Czartoryskiego zakupy rzeźb w Rzymie (1800-1801)
}

\author{
Prince Czartoryski's Purchases of Sculptures \\ in Rome (1800-1801)
}


Artykuł poświęcony jest kontaktom księcia Adama Jerzego Czartoryskiego z włoskimi rzeźbiarzami oraz zakupom rzeźb dokonywanym przez niego podczas pobytu w Rzymie od sierpnia 1800 do maja $1801 \mathrm{r}$. Na podstawie korespondencji księcia z matką, Izabelą Czartoryską, a także licencji na wywóz dzieł dzieł sztuki poza granice Państwa Papieskiego przechowywanych w Archivio di Stato di Roma oraz wzmianek w diariuszu rzymskiego rzeźbiarza i antykwariusza Vincenza Pacettiego, udało się zrekonstruować obraz ówczesnych artystycznych zainteresowań księcia Czartoryskiego, jego relacji ze środowiskiem rzymskich rzeźbiarzy i antykwariuszy oraz kupowania przez niego rzeźb i udziału w przywiezieniu do Puław w 1803 r. m.in. znajdujących się tam do dziś: posagu fauna (przed 1800), figury śpiącej pantery (1801) oraz marmurowego sarkofagu dzieła Francesca Massimiliana Laboureura (1797).

Słowa-klucze: Adam Jerzy Czartoryski (1770-1861, Puławy-zbiory artystyczne, kolekcjonerstwo, Rzym-handel sztuką, mecenat artystyczny

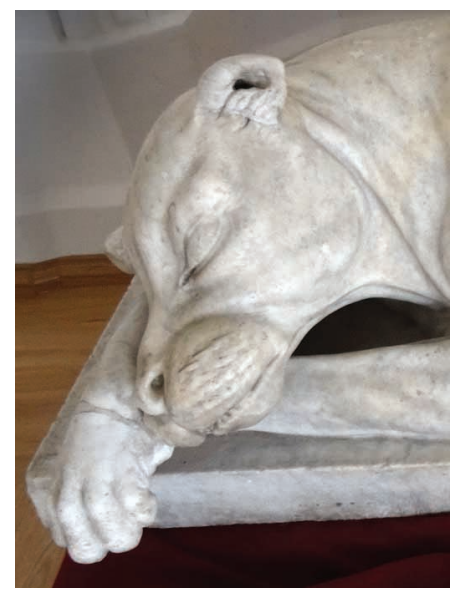

Prince Adam Jerzy Czartoryski's contacts with Italian sculptors and purchases of sculptures during his stay in Rome from August 1800 to May 1801 are discussed. Resorting to the correspondence of Prince Czartoryski with his mother Izabela Czartoryska, licenses to export art works beyond the Papal States kept in the Archivio di Stato di Roma, and notes in the diary of the Roman sculptor and antique dealer Vincenzo Pacetti, it was possible to reconstruct picture of the then interests of Prince Czartoryski, his relations with Rome's circle of sculptors and antique dealers, as well as of his purchase of sculptures and efforts made to have, among others, the following transported to Puławy in 1803, where they have been preserved to-date: the statute of a faun (before 1800), figure of a sleeping panther (1801), and the marble sarcophagus by Francesco Massimiliano Laboureur (1797).

Keywords: Adam Jerzy Czartoryski (1770-1861, Puławy-art collection, collecting, Rome-art trade, artistic patronage 
K

siążę Adam Jerzy Czartoryski (1770-1861), syn Adama Kazimierza i Izabeli z Flemingów, otrzymał staranne wykształcenie, a w młodości sporo podróżował ${ }^{1}$. Szwajcarię, Holandię do Anglii, Szkocji i Francji, był też w Wiedniu, Paryżu, Londynie i Brukseli. W początkach 1795 r. rodzice wysłali go wraz z bratem Konstantym Adamem na carski dwór do Sankt Petersburga w celu ratowania rodzinnych dóbr zasekwestrowanych przez Rosjan. Książę pozostawał tam od końca maja 1795 r. przez kilka następnych lat. Swoją nieco przymusową karierę dyplomatyczną w służbie rosyjskiej Adam Jerzy Czartoryski rozpoczął jako przedstawiciel cara Pawła I przy dworze króla Sardynii Karola Emanuela IV, mianowany na to stanowisko 12 sierpnia 1799 r. $^{2}$ Wygnany przez Napoleona ze swojego królestwa Karol Emanuel zamieszkał jesienią tego roku w Villa di Poggio Imperiale koło Florencji ${ }^{3}$. Czartoryski, jadąc do Włoch przez Wiedeń (il. 1), przybył do Florencji w ostatnich dniach grudnia 1799 r. Do połowy następnego roku spędzał tam czas w pozornej misji dyplomatycznej, nawiązując stosunki z miejscowym towarzystwem włosko-austriackim. Po zwycięskiej dla Francuzów bitwie pod Marengo w połowie czerwca 1800 r., król Sardynii został zmuszony do opuszczenia swej siedziby i wyjechał do Rzymu ${ }^{4}$. Książę Czartoryski podążył za nim. Do Rzymu przyjechał w końcu lipca i pozostał tam do kwietnia 1801 r. W kwietniu wyjechał na krótko do Neapolu, gdzie dowiedział się o śmierci cara Pawła I, zamordowanego 24 marca 1801 r. Na rozkaz nowego cesarza Rosji, Aleksandra I, Czartoryski opuścił Włochy. Jadąc z Neapolu przez Rzym i Florencję, a następnie przez Wiedeń i Puławy, powrócił do Petersburga w początkach lipca $1801 \mathrm{r}$.

We Włoszech trzydziestoletni wówczas książę Czartoryski przebywał niemal półtora roku - od jesieni 1799 do wiosny 1801 r. Był to jego pierwszy pobyt w tym kraju. Pobytowi temu książę poświęcił trochę miejsca w swoich pamiętnikach, pisanych pół wieku

\footnotetext{
${ }^{1}$ Zob. Marceli Handelsman, „Czartoryski Adam Jerzy”, w: Polski słownik biograficzny, t. 4 (Kraków: PAU, 1938), s. 257-269; zob. też: Bronisław ZALESKI, Żywot księcia Adama Jerzego Czartoryskiego (Poznań: J.K. Żupański, 1881).

${ }^{2}$ Czartoryski, będąc adiutantem wielkiego księcia Aleksandra, nawiązał romans z jego żoną, wielką księżną Elżbietą Aleksiejewną; po urodzeniu przez księżnę córki został mianowany przez cara Pawła I posłem rosyjskim w Królestwie Sardynii.

${ }^{3}$ Karol Emanuel IV (1751-1819) był królem Sardynii w latach 1796-1802. W 1796 r. wojska Napoleona zajęły kontynentalne terytorium jego królestwa, w końcu 1798 r. został zmuszony do oddania Piemontu. Wyjechał wraz z żoną (Marią Klotylda, siostrą Ludwika XVI) z Turynu do Parmy i Florencji, a w lutym 1799 r. na Sardynię. Po uwolnieniu od Francuzów przez oddziały rosyjskie jego terytoriów na półwyspie włoskim, car Paweł I oddał koronę wygnanemu królowi, który zdecydował się wrócić z Sardynii. Jednak gdy wylądował w Livorno 22 IX 1799 r. okazało się, że Rosjanie oddali Piemont Austriakom niepopierającym jego powrotu, zdecydował się zatem zatrzymać w Villa di Poggio Imperiale koło Florencji.

${ }^{4}$ Karol Emanuel IV przybył do Rzymu 5 VII 1800 r. Między 1800 a 1802 r. mieszkał z żoną między Rzymem, Frascati, Neapolem i Caserta, a gdy królowa Maria Klotylda zmarła 7 III 1802 r., wrócił do Rzymu i 4 VI abdykował na rzecz swojego brata Wiktora Emanuela I.
} 


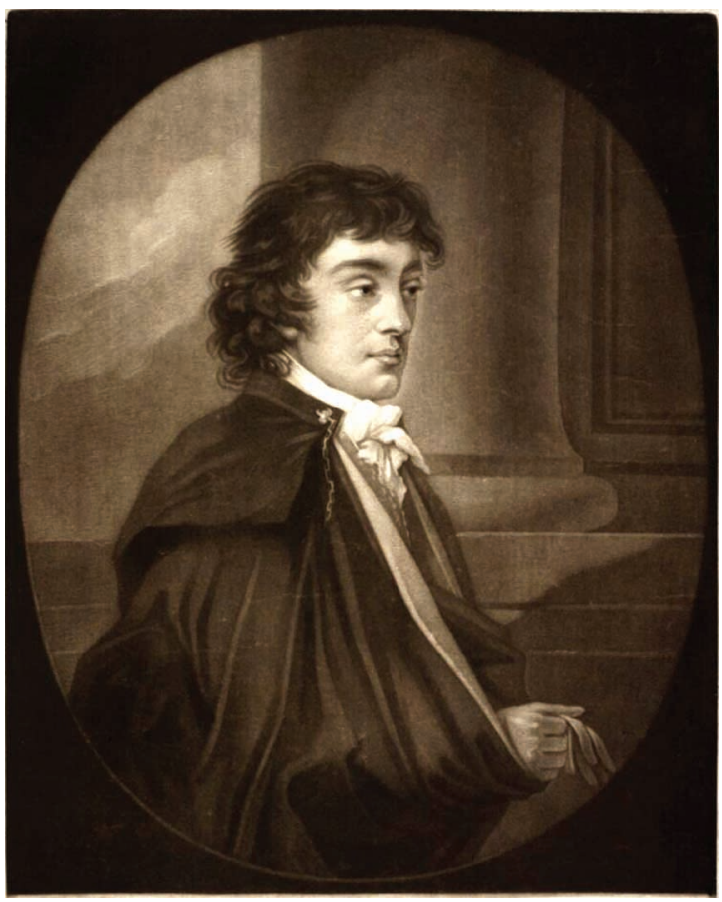

1. Andreas Geiger wedtug obrazu Josepha Abela, Adam Jerzy Czartoryski, mezzotinta,

Wiedeń, 1799, Warszawa, Biblioteka Narodowa. Fot. polona.pl

później i kilkakrotnie publikowanych ${ }^{5}$. Wspomina w nich, że wówczas „Włochy były w smutnym stanie [...]. Kraj wojną opustoszały, mieszkańcy lękliwi"6. O pobycie we Florencji, gdzie król Karol Emanuel IV otoczony był kilkoma jedynie wiernymi stronnikami, Czartoryski pisał, że całe towarzystwo składało się tam z kilku Piemontczyków i piemonckich rodzin, które ze swym królem udały się na wygnanie, a miejscowego wcale nie było, „,każden żył u siebie i nikogo nie widywał"7. Wyjątkiem był dom hrabiny d'Albany i włoskiego pisarza Vittoria Alfieri, gdzie na obiady zapraszani byli wszyscy cudzoziemcy, a domownikiem był malarz François-Xavier Fabre ${ }^{8}$. Czartoryski poznał austriackiego generała Hannibala Sommarivę, będącego wówczas „figurą najznakomitszą we Florencji”, odwiedzał mieszkającego w Pizie marszałka Franciszka Rzewuskiego, przyjaciela rodziców, pojechał też do Livorno ${ }^{9}$. Pozostały czas, jak pisał, wykorzystywał ,na zwiedzanie arcydzieł sztuki i wszystkich ciekawości zebranych w galeriach florenckich oraz na zajęcie się nauką języka włoskiego, w którym odczytywałem Dantego"10. Ten stan „spokoju i nudy”

\footnotetext{
${ }^{5}$ Pamiętniki ks. Adama Czartoryskiego i jego korespondencja z cesarzem Aleksandrem I, oprac. Lubomir GADon, Karol de MAZADE, thum. z francuskiego Karol Scipio, t. 1-2 (Kraków: Spółka Wydawnicza Polska, 1904-1905); o pobycie we Włoszech: t. 1, s. 126-144. Wcześniejsze edycje: Mémoires du prince Adam Czartoryski et correspondance avec l'Empereur Alexandre I'. Préface de M. Ch[arles] de Mazade, t. 1-2 (Paris: E. Plon, 1887); Memoirs of Prince Adam Czartoryski and his correspondence with Alexander I: with documents relative to the prince's negotiations with Pitt, Fox and Brougham, and an account of his conversations with Lord Palmerston and other English statesmen in London in 1832, wyd. Adam Gielgud, t. 1-2 (London: Remington, 1888). Fragment pamiętników poświęcony pobytowi księcia we Włoszech zob. „W dalszym ciaggu listów księcia Adama Czartoryskiego. Przez Sewerynę Duchińską”, Kronika Rodzinna, nr 19 (1887), s. 580-583. Por. Adam Jerzy CzARToRYski, Pamiętniki i memorialy polityczne 1776-1809, oprac. Jerzy SKowronek (Warszawa: Instytut Wydawniczy „PAX”, 1986); o pobycie we Włoszech: s. 260-277.

${ }^{6}$ CZARTORYSKI, Pamiętniki, s. 261.

${ }^{7}$ Ibid., s. 263.

${ }^{8} \mathrm{O}$ związkach Polaków z florenckim salonem Luizy von Stolberg hrabiny Albany i z jej bliskim przyjacielem malarzem François-Xavierem Fabre zob. Andrzej Ryszkiewicz, Francusko-polskie zwiazki artystyczne: w kregu J.L. Davida (Warszawa: WAiF, 1967), s. 111-117.

${ }^{9}$ Czartoryski, Pamiętniki, s. 263-265.

${ }^{10}$ Ibid., s. 265.
} 
trwał do czasu, gdy dowiedziano się o bitwie pod Marengo i o jej skutkach; wówczas „król i wszyscy, co przy nim byli i ja z nimi, pojechaliśmy do Rzymu”11.

Podczas pobytu w Rzymie Czartoryski interesował się historią i sztuką tego miasta. Jak wspominał po latach, ,przejęcie się starożytnością Rzymu stało się przez czas mojego pobytu w tym przesławnym mieście moją prawie jedyną myślą". Zamierzał wykonać plan starożytnego Rzymu i zamówić serię rysunków odtwarzających jego przeszłość, a w każdym z nich chciał „mieć wystawioną jakąś scenę, przypadającą do dziejów jej epoki”. Pisał: „Nie potrafiłem dokonać tej pracy i tylko ją rozpocząłem. Dostałem plan Rzymu, wcale dobrze wyrobiony, jako podstawę całego przedsięwzięcia, i dwa rysunki: jeden przedstawiający Forum za Rzeczypospolitej, naprzeciw Palatynu i na nim zebranie ludu [...]. Druga zaś wielka akwarela wystawiała tenże Forum, lecz z przeciwka Kapitolu i triumf Germanika za Tyberiusza [...]. Trzecia akwarela, w mojej nieobecności zrobiona, miała wystawiać pierwsze czasy po założeniu Rzymu, groty koło Tybru pod Palatynem, ale nie była trafnie i podług mojej myśli wykończona. Te kilka rysunków pozostały śladem mojej bytności w Rzymie"12.

Czartoryski „bardzo był kontent” z rozkazu cesarza, który polecał mu opuścić Rzym i udać się do Neapolu, bo dawało mu to sposobność poznania tego miasta. Pisał: „W Neapolu czas łatwo mi schodził, nie spieszyłem się obzierać wszystkie miejscowe naturalne i artystyczne ciekawości (te ostatnie od rewolucji były w upadającym stanie), kiedy jak piorun w czasie pogodnym przyszła wiadomość o śmierci cesarza Pawła"13. Rozkaz nowego cesarza, nakazującego mu niezwłoczny powrót do Petersburga, jak pisał, „ucieszył mnie niemało. Choć Włochy są ciekawym, nauczającym, rozkosznym krajem [...] jednak tam byłem daleko od kraju, od rodziny [...]. Z niewymowną więc radością pomyślałem o wyjeździe”. Ponieważ jednak ,trudno było porzucić Neapol, nie widziawszy Wezuwiusza, Pompei, Herkulanum, Portici, Baja itp.”, zwiedził pośpiesznie wszystkie te miejsca ${ }^{14}$. Po krótkim pobycie w Rzymie i kilku dniach spędzonych we Florencji książę Czartoryski opuścił Włochy, udając się do Wiednia, a stamtąd przez Puławy powrócił do Petersburga.

W pamiętniku księcia Czartoryskiego nie ma wzmianek o jego kontaktach z włoskimi artystami ani o nabywanych przezeń dziełach sztuki. Tymczasem podczas dziewięciu miesięcy spędzonych w Rzymie Adam Jerzy Czartoryski nawiązał stosunki z tamtejszymi rzeźbiarzami i kupował u nich rzeźby ${ }^{15}$. Wielu wiadomości na ten temat dostarcza korespondencja, jaką przebywający we Włoszech książę prowadził z matką, Izabelą Czartoryską ${ }^{16}$. Niektóre fragmenty listów księżny do syna dotyczące tych kwestii zostały opublikowane w latach 80. XIX w. przez Sewerynę Duchińską ${ }^{17}$ i Ludwika Dębickiego ${ }^{18}$,

\footnotetext{
${ }^{11}$ Ibid., s. 265-266.

12 Ibid., s. 266-267.

13 Ibid., s. 270, 273.

14 Ibid., s. 273-274.

15 Zob. Katarzyna Miкоска-Raснuвowa, Canova, jego krag i Polacy (około 1780-1850) (Warszawa: Instytut Sztuki PAN, 2001), t. 1, s. 105; t. 2, s. 216-218; EAD., Rzeźba włoska w Polsce około 1770-1830 (Warszawa: Instytut Sztuki PAN, 2016), t. 1, s. 94; t. 2, s. 326-330 (tamże wcześniejsza literatura).

${ }^{16} \mathrm{~W}$ listach kilkakrotnie jest mowa o planowanym przez Izabelę Czartoryską przyjeździe do syna do Włoch. Z zamierzeń tych jednak ostatecznie nic nie wyszło, a księżna nigdy nie była we Włoszech.

17 „Listy księżny Izabelli z hr. Flemmingów Czartoryskiej do starszego syna swego księcia Adama. Przez Sewerynę Duchińską", Kronika Rodzinna, nr 20, nr 1 (1887), s. 10; nr 6 (1887), s. 161, 162, 163; Listy księżny Izabelli z hr. Flemmingów Czartoryskiej do starszego syna księcia Adama. Zebrała Seweryna Duchińska (Kraków: G. Gebethner i Spółka, 1891), s. 49-50, 64, 65, 66, 67-68, 69, 71-72.

${ }^{18}$ Ludwik DęBICKI, Puławy (1762-1830). Monografia z życia towarzyskiego, politycznego i literackiego na podstawie
} 
na wzmianki te powołują się też późniejsi badacze ${ }^{19}$. Dziewiętnastowieczni autorzy nie uwzględnili jednak wszystkich istotnych informacji zawartych w listach Izabeli Czartoryskiej, przytoczone przez nich cytaty pomijają niektóre passusy, a fragmenty pisane w języku francuskim podano w tłumaczeniu, nie zaznaczając tego. W dotychczasowych badaniach nie wykorzystano listów do matki pisanych przez Adama Czartoryskiego z Włoch, w których znajduje się wiele informacji dotyczących jego poczynań związanych ze sztuką ${ }^{20}$. Kilka wzmianek o rzeźbach zakupionych przez księcia we Włoszech odnajdujemy w licencjach na wywóz dzieł sztuki poza granice Państwa Papieskiego, przechowywanych w zasobach Archivio di Stato w Rzymie. O zainteresowaniu księcia Czartoryskiego rzeźbami i ich zakupem pisał też w swoim dzienniku znany rzymski rzeźbiarz i antykwariusz Vincenzo Pacetti. Wszystkie te materiały pozwalają na ukazanie aspektu zainteresowania księcia Czartoryskiego kwestiami artystycznymi i przedstawienie jego działań na tym polu w pełniejszym świetle, a także na sprostowanie niektórych nieścisłych lub błędnych informacji, jakie funkcjonują w dotychczasowej literaturze.

W czasie kilkumiesięcznego pobytu we Florencji (od stycznia do lipca 1800 r.) książę Czartoryski interesował się sprawami artystycznymi i tamtejszą sztuką. W pierwszych dniach po przyjeździe pisał do matki, że gdyby chciała mieć obraz jakiegoś sławnego malarza lub kopię takiego dzieła, to mógłby go dla niej kupić, można tu bowiem nabyć dzieła lepsze i za lepszą cenę niż gdziekolwiek indziej. Proponował też rodzicom zakup świeżo wydanej pracy o wazach etruskich, uważanej za lepszą niż poprzednia, której subskrypcja kosztuje około trzydziestu dukatów. We Florencji książę poznał, jak pisał, wielu utalentowanych malarzy i innych artystów, np. rytownika gemm i kamei (intagliatora), który po śmierci Giovanniego Pichlera (1791) uznawany był za pierwszego w swej sztuce w Italii ${ }^{21}$. W następnych miesiącach książę pisał do matki, że od dawna zamierza stworzyć kolekcję rycin prezentujących najwybitniejsze prace sławnych mistrzów, gdzie podstawowym kryterium wyboru dzieł będą nie ich technika czy unikalność, ale doskonałość rysunku i kompozycji. W realizacji tego zamierzenia pomaga mu malarz Fabre, uczeń Davida, który sam ma podobną kolekcję i odstępuje mu niektóre obiekty, które posiada ${ }^{22}$. Czartoryski pisał, że sam też rysuje zarówno w domu, jak chodząc po mieście ${ }^{23}$. W listach wspomina mieszkającego wówczas we Florencji „Eygnera” (chodziło niewątpiwie o malarza Karola Barłomieja Aignera, syna Chrystiana - stolarza Czartoryskich w Puławach, a brata architekta Chrystiana Piotra), który „mało ma wcale talentu i znajomości, to jest

archiwum ks. Czartoryskich w Krakowie, t. 4: Czartoryscy w literaturze (Lwów: Nakładem księgarni Gubrynowicza i Schmidta, 1888), s. 113, 114, 115, 116, 117.

19 Tomasz MiкоскI, „Sztuka starożytna w mecenacie Izabelli Czartoryskiej”, Meander 38, nr 6 (1983), s. 216-217; ID., Najstarsze kolekcje starożytności w Polsce (lata 1750-1830) (Wrocław: Ossolineum, 1990), s. 75-76.

${ }^{20}$ Zwróciła na nie uwagę Zofia GoŁĘBIowskA, „Mecenat kulturalny Izabeli i Adama Kazimierza Czartoryskich (sztuki plastyczne, teatr, muzyka, literatura)", w: Ziemiaństwo na Lubelszczyźnie. Materiały II sesji naukowej zorganizowanej w Muzeum Zamoyskich w Kozłówce 22-24 maja 2002, red. Róża MaLiszewska (Kozłówka: Muzeum Zamoyskich, 2003), s. $58-59$.

${ }^{21}$ Biblioteka Książąt Czartoryskich w Krakowie (dalej: BCzart.), rkps 6097: Listy Adama Jerzego Czartoryskiego do matki Izabeli z Flemingów Czartoryskiej z lat 1789-1801 (pisane w języku francuskim, z wtrąconymi niekiedy pojedynczymi zdaniami po polsku), s. 132-133 (list księcia z Florencji 18 I 1800); też s. 135-136 (list z Florencji 8 II 1800).

22 BCzart., rkps 6097, s. 147 (list księcia z Florencji 10 III 1800), s. 155-156 (list z Florencji 29 III 1800).

${ }^{23}$ BCzart., rkps 6097, s. 162 (list księcia z Florencji 8 IV 1800). 


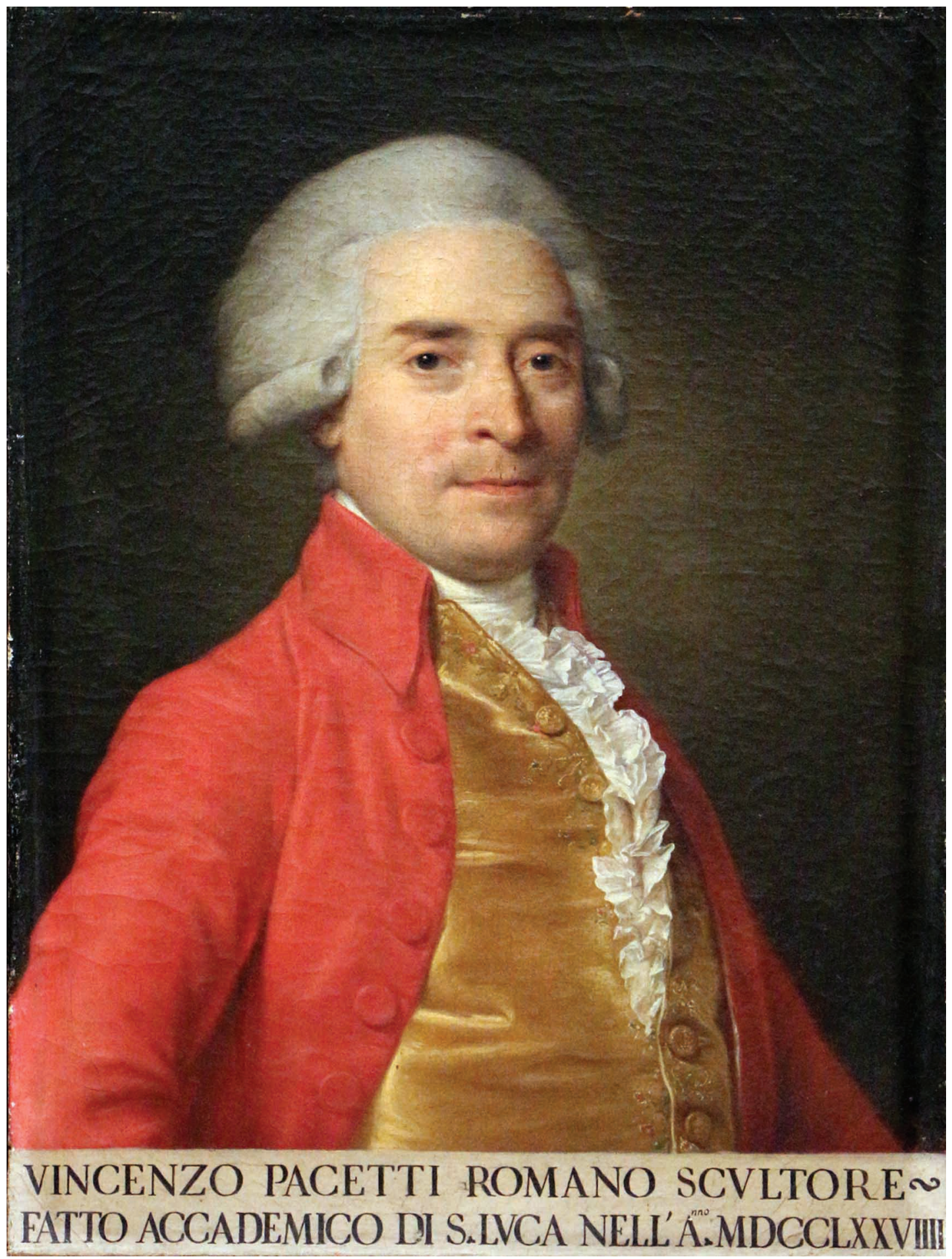

2. Anton van Maron, Vincenzo Pacetti, olej, płótno, 1790, Rzym, Accademia Nazionale di San Luca, inv. 248. Fot. www.accademiasanluca.eu 
uważając, że 10 lat już przesiedział w Rzymie"24. Przed wyjazdem z Florencji starał się umieścić go u jakiegoś dobrego malarza (,zostawię tu Eignera u malarza dobrego, nie wiem czy z niego co będzie" $)^{25}$.

Do Rzymu książę Czartoryski przyjechał w końcu lipca lub może w pierwszych dniach sierpnia 1800 r. $^{26}$ Wkrótce po przyjeździe pisał do matki, że zamierza zamówić kilka rysunków przedstawiających dawny Rzym, na których w każdym z miejsc znalazłyby się jakieś współczesne sceny ${ }^{27}$. Nawiązał do tego kilka miesięcy później, pisząc w początkach marca następnego roku: „Teraz się zatrudniam robieniem karty dawnego Rzymu, której dotychczas dobrej wcale jeszcze nie ma, a która po tym ma służyć za grunt rysunkom, które chcę kazać robić. Dość przyjemnie czasem ranki trawię śledząc i mierząc dawne a zaniedbane gruzy”. Ubolewa przy tym, że „te reszty dawnej wielkości które sąjedyną wartością teraźniejszego Rzymu są zaniedbane, zarzucone i wcale opuszczone, tak że coraz bardziej giną" 28 . W kwietniu, przed wyjazdem do Neapolu, książę żałował, że wyjeżdża nie skończywszy pracy nad planem miasta, która jest bardzo zaawansowana, ale na ukończenie jej potrzeba mu jeszcze dwóch miesięcy. Miał nadzieję dokończyć ją po powrocie do Rzymu i dołączyć wówczas do planu rysunki z widokami antycznego miasta ${ }^{29}$.

Spośród inicjatyw na polu sztuki na szczególną uwagę zasługują poczynania księcia Czartoryskiego związane z rzeźbą ${ }^{30}$. W pierwszych dniach swojego pobytu w Rzymie, w połowie sierpnia 1800 r., książę nawiązał kontakt z rzymskim rzeźbiarzem Vincenzem Pacettim (1746-1820), który zajmował się głównie restaurowaniem antycznych rzeźb, wykonywaniem ich kopii oraz handlem dziełami sztuki, co przyniosło mu majątek i sławę $^{31}$ (il. 2). Artysta prowadził przez 46 lat swojego życia diariusz, w którym zapisywał wszelkie wydarzenia z własnej działalności, a także informacje i opinie o osobach odwiedzających jego pracownię i kupujących tam rzeźby ${ }^{32}$. W diariuszu znalazły się wzmianki

\footnotetext{
${ }^{24}$ BCzart., rkps 6097, s. 172 (list księcia z Florencji 17 VI 1800).

${ }^{25}$ BCzart., rkps 6097, s. 176 (list księcia z Florencji 5 VII 1800).

${ }^{26}$ Czartoryski pisał do matki 18 VII 1800 r. z Pizy, że za parę dni wyjeżdża do Rzymu (BCzart., rkps 6097, s. 177), a list z 9 VIII jest już datowany z Rzymu (ibid., s. 178).

${ }^{27}$ BCzart., rkps 6097, s. 188-189 (list księcia z Rzymu 30 VIII 1800).

${ }^{28}$ BCzart., rkps 6097, s. 221 (list księcia z Rzymu 2 III 1801).

${ }^{29}$ BCzart., rkps 6097, s. 230-231 (list księcia z Rzymu 10 IV 1801). Pozostałością owych zamierzeń jest być może przechowywany w zbiorach Biblioteki Książąt Czartoryskich w Krakowie rkps 1750: Repertorio di erudizioni e notizie correlative alla nuova topografica pianta dell'antica Roma, da delinearsi nel 1802 per ordine di sua Altezza il signor principe Adamo Czartoriski. Zwrócili na to uwagę: Zdzisław Żygulski (Jun.), „Dzieje zbiorów puławskich (Świątynia Sybilli i Dom Gotycki)", Rozprawy i Sprawozdania Muzeum Narodowego w Krakowie 7 (1962), s. 205-206; Dziennik podróży do Francji i Włoch Augusta Moszyńskiego architekta JKM Stanisława Augusta Poniatowskiego, 1784-1786, oprac. i thum. Bożena ZBoiŃSKA-DASZYŃSKa (Kraków: Wydawnictwo Literackie, 1970), s. 17-18; zob. też: MiкоскI, „Sztuka starożytna”, s. 214-215.

${ }^{30}$ Wspomnieć też należy, że prawdopodobnie w drodze powrotnej z Włoch, w maju 1801 r., Adam Jerzy Czartoryski kupił w Wenecji obraz Rafaela Portret młodzieńca z kolekcji Giustiniani, a także Damę z gronostajem Leonarda da Vinci . Oba obrazy ofiarował matce i od 1809 r. były one w Domu Gotyckim w Puławach (obecnie obraz Leonarda znajduje się w Muzeum Książąt Czartoryskich-Muzeum Narodowym w Krakowie, a obraz Rafaela zaginął w 1945 r.). Por. Janusz WaŁeK, „Rafaela Portret młodzieńca ze zbiorów Czartoryskich”, Artibus et Historiae 12, nr 24 (1991), s. 201-224; ID., „Rafaela Portret młodzieńca ze zbiorów Czartoryskich”, Rozprawy Muzeum Narodowego w Krakowie. Seria nowa 1 (1999), s. 13-82.

31 O nim ostatnio: Miкоска-Rachubowa, Rzeźba włoska w Polsce około 1770-1830, t. 2: Katalog, s. 407-422 (tamże wcześniejsza literatura) oraz t. 1-2 według indeksu.

${ }^{32}$ Diariusz zachowany w dwóch częściach: pierwsza (lata 1773-1803) jest przechowywana w Biblioteca Universitaria Alessandrina w Rzymie (ms 321: Giornale di Vincenzo Pacetti riguardante li principali affari, e negozj del suo studio di scultura, ed altri suoi interressi particolari, incominciato dall'anno 1773 fino all'anno 1803), a druga (lata 1803-1819)
} 
3. Śpiący Faun (Faun Barberini), marmur biaty, ok. 200 p.n.e., Monachium, Gliptoteka.

Fot. commons.wikimedia.org

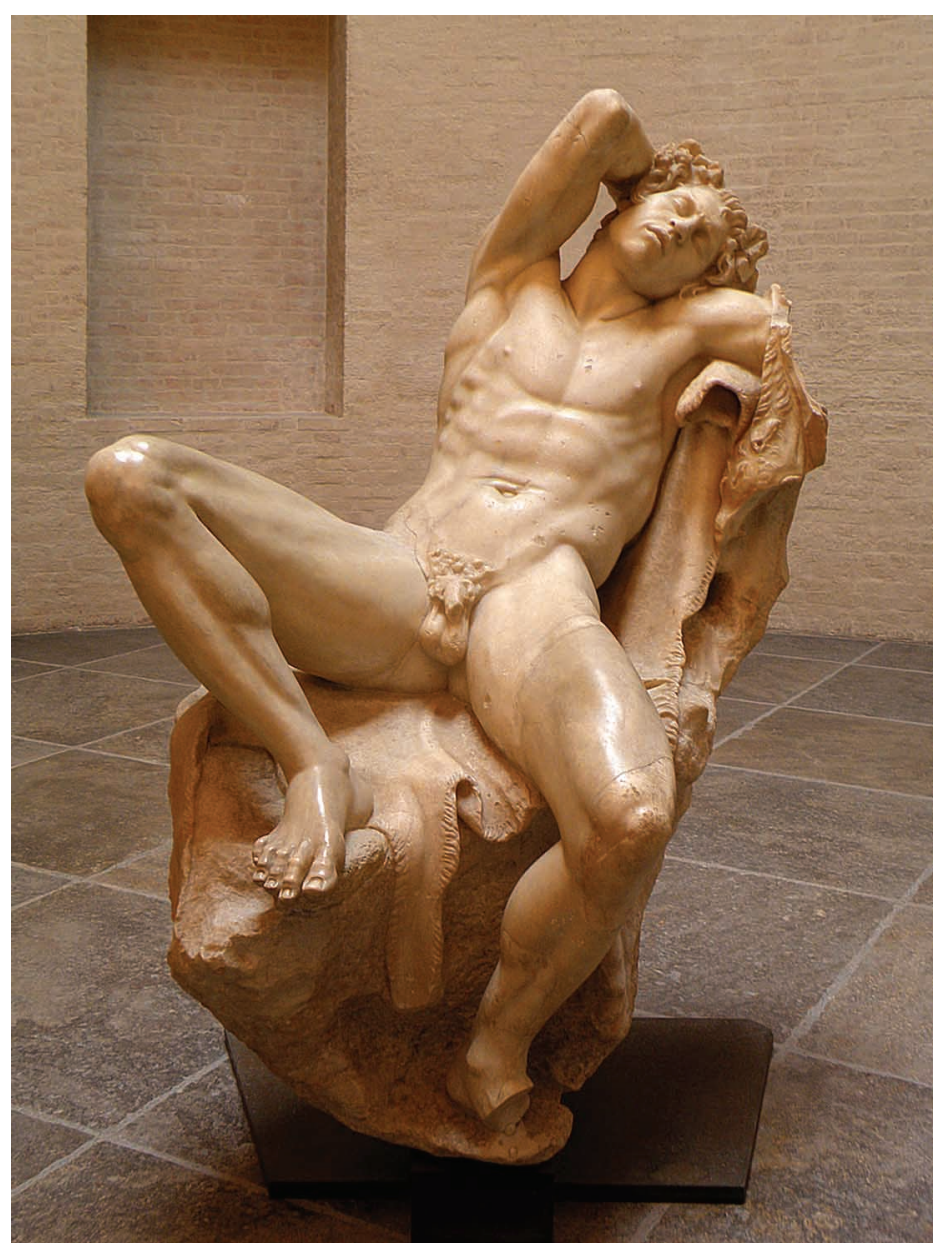

dotyczące księcia Czartoryskiego. Książę kilkakrotnie odwiedzał Pacettiego i oglądał u niego rzeźby, a szczególną jego uwagę zwrócił posag Fauna. Pacetti złożył mu ofertę zakupu tego dzieła, a Czartoryski w sierpniu i w następnych miesiącach kilkakrotnie przychodził je oglądać. Pacetti zapisał 12 sierpnia, że „Conte Casini” ${ }^{\prime 3}$ przyprowadził do niego „il ministro di Russia di Torino” (czyli Czartoryskiego), aby pokazać mu Fauna; przypomniał też artyście, że on sam oferował mu dawniej za tę rzeźbę 7000 piastrów, na co Pacetti odpowiedział, że obecnie najniższa cena to 6000 cekinów $^{34}$. Następnego dnia zanotował, że opat Marini powiedział mu, iż ambasador Czartoryski chce dokonać zakupu jakiejś wyjątkowej (sublime) rzeczy i że byłaby to okazja do sprzedaży Fauna, trzeba

w Museo Centrale del Risorgimento w Rzymie (busta 654, fasc. 5: Giornale delle cose più importanti di pertinenza di Vincenzo Pacetti fin ora scritto in fogli volanti: ma da quest'epoca in poi, tutti si riportano per alfabeto a seconda delle loro casate, o sieno cognomi rispettivi questo di 15. Maggio 1803, 1803-1819). Dziennik Pacettiego (dalej: Giornali di Pacetti) został ostatnio opublikowany: Roma 1771-1819. I „, Giornali” di Vincenzo Pacetti, red. Angela CipRIANi et al. (Pozzuoli: Naus Editoria, 2011). Obie części dziennika zostały wykorzystane w kontekście kontaktów Pacettiego z Polakami w: Katarzyna Miкоска-Rachubowa, ,Rzeźbiarz rzymski Vincenzo Pacetti i Polacy”, Biuletyn Historii Sztuki 65, nr 2 (2003), s. 261-276; EAD., „O Giornale Vincenza Pacettiego raz jeszcze”, Biuletyn Historii Sztuki 68, nr 1 (2006), s. 103-105.

${ }^{33}$ Vittorio Maria Gioachino Capizucchi, hrabia di Cassine di Strada (1754-1811) - rosyjski konsul generalny w Rzymie w latach 1795-1801.

34 Giornali di Pacetti, s. 209: „Adi 12. [Agosto 1800] Il Signor Conte Casini mi hà condotto il ministro di Russia di Torino per fargli vedere il mio Fauno rimproverandomi, che potevo aver preso da lui tempo fà settemila piastre, che mi offeri, e a quest'ora ne avrei fatto del denaro altro profitto, o con nuovi acquisti, o con un fruttato: avendogli io riposto, che il ristretto prezzo sono seimila zecchini. Il Conte Sartorischi („Il Conte Sartorischi” dodane nad wierszem). 
zatem nalegać na księcia, aby go kupił ${ }^{35}$. W dniu 15 sierpnia Pacetti odwiedził zatem księcia Czartoryskiego i złożył mu ofertę zakupu Fauna (,l’offerta del mio Fauno”) mówiąc, że wprawdzie były co do tej rzeźby pewne układy, ale może nią nadal swobodnie dysponować, nie będąc związany żadną umową ${ }^{36}$. Pacetti jednocześnie próbował też sprzedać Fauna innym klientom, np. w końcu sierpnia starał się, aby zakupiono go na dworze w Petersburgu ${ }^{37}$.

W następnym miesiącu Czartoryski dwukrotnie (10 i 11 września) odwiedzał Pacettiego w towarzystwie opata Mariniego, aby obejrzeć jego antyki ${ }^{38}$. Jeszcze 12 października Pacetti był u księcia, aby porozmawiać o Faunie, a Czartoryski miał przyjść obejrzeć tę rzeźbę ${ }^{39}$. Wiele miesięcy później, 19 marca 1801 r., Pacetti odwiedził księcia Czartoryskiego, a gdy ten zapytał go o Fauna, artysta odpowiedział, że ów ,ancora dormiva" 40 (,sprawa stoi w miejscu”). Domyślać się można, że rzeźbą oferowaną Czartoryskiemu był sławny Faun (Śpiacy Satyr) znany jako Faun Barberini (il. 3), antyczny posąg w marmurze będący od początków XVII w. własnością rodu Barberinich, od których Pacetti zakupił go w 1798 r. Odrestaurował Fauna i następnie bezskutecznie starał się go sprzedać jakiemuś zamożnemu cudzoziemcowi. W 1804 r. Barberini odzyskali rzeźbę, a w 1814 r. kupił ją Ludwik Bawarski i Faun pozostaje obecnie w zbiorach Gliptoteki w Monachium ${ }^{41}$.

Zupełnie nieznanym dotychczas faktem było przyjęcie Czartoryskiego do Akademii św. Łukasza, co książę zawdzięczał protekcji Pacettiego, pełniącego w 1801 r. funkcję „principe” tejże instytucji. Pacetti zapisał w diariuszu pod datą 1 lutego 1801 r., że dzięki

${ }^{35}$ Giornali di Pacetti, s. 209: „Adi 13. [Agosto 1800] Mi a detto l'Abate Marini, che il suddetto Ambasciatore Sartorischi vol fare un acquisto di una cosa sublime, ed il mio Fauno sarebbe al caso sicché bisogna insisterci appresso il medesimo per procurare se gli si potesse vendere”.

${ }^{36}$ Giornali di Pacetti, s. 209: „Adi 15. [Agosto 1800] Sono andato dal Signor Principe Sartorischi, al quale hò fatta l'offerta del mio Fauno avendogli detto, che avevo dei trattati, ma che ero in libertà poterne disporre non avendo compromesso la mia parola con alcuno gli ò detto, che ne avevo scritto al Signor Brenna e n'aspettavo riposta. Mi a parlato di Tonci sopra alcuni interressi suoi”.

37 Giornali di Pacetti, s. 209: „Adi 21. [Agosto 1800] Ieri fui dal Signor Conte Casini, il quale in breve partirà per Pietroburgo, gli ò parlato del mio Fauno ed egli mi disse, che tempo addietro, quando egli avrebbe potuto comprarlo e mi offerì fino a piastre ottomila non lo volli dare; ma che procurerà di fare il possibile di farlo acquistare alla sua corte essendo una cosa così celebre".

${ }^{38}$ Giornali di Pacetti, s. 210: „Adi 10.11. [7bre 1800] E tornato il Principe Sartorischi con un altroSignore, e l'Abate Marini per vedere le mie antichità".

${ }^{39}$ Giornali di Pacetti, s. 211: „Adi 13. [8bre 1800] Ieri sono stato dal Signor Principe Sartorischi per parlargli del mio Fauno il quale verrà a vederlo".

${ }^{40}$ Giornali di Pacetti, s. 215: „Adi 19. [Marzo 1801] Sono stato dal Signor principe Sartorischi, il quale mi à domandato del mio Fauno ed o gli ò riposto che ancora dormiva".

${ }^{41}$ Śpiacy Satyr (Faun Barberini), marmur, wys. 178 cm, ok. 200 p.n.e. - dzieło rzeźbiarza hellenistycznego ze szkoły pergamońskiej lub rzeźbiarza rzymskiego, wykonane według oryginału w brązie. Po odkryciu go ok. 1624 r. posag został własnością rodu Barberinich, w 1628 stał już w Palazzo Barberini w Rzymie. Rzeźba była kilkakrotnie poddawana restauracjom: w latach 1628 i 1635 Arcangelo Gonelli ułożył fauna na wznak, a w 1679 r. Giuseppe Giorgetti i Lorenzo Ottoni zmienili ułożenie postaci i dokonali stiukowych uzupełnień brakujących elementów (efekty ich prac przypisano później błędnie Gianlorenzo Berniniemu). W 1798 r. posąg został kupiony przez Vincenza Pacettiego na aukcji w Palazzo Barberini za 800 skudów. Pacetti po zakupie odrestaurował rzeźbę, wymienił XVII-wieczne stiukowe uzupełnienia nogi figury na marmurowe i przesunął jej prawą stopę, po czym bezskutecznie starał się sprzedać posąg. Barberini w 1804 r. odzyskali rzeźbę na drodze sądowej. Ostatecznie w 1814 r. posąg został zakupiony przez Ludwika I Bawarskiego i pomimo wielu protestów, po kilku latach dyplomatycznych presji w 1819 r. opuścił Wieczne Miasto. W 1820 r. przybył do Monachium, od 1827 r. pozostaje w zbiorach tamtejszej Gliptoteki. Zob. Francis HasKELL, Nicholas Penny, Taste and the Antique. The Lure of Classical Sculpture 1500-1900 (New Haven-London: Yale University Press, 1982), s. 202-205 poz. 33. 
jego staraniom książę Adam Czartoryski został akademikiem honorowym, wybranym przez aklamację ${ }^{42}$.

W połowie stycznia $1801 \mathrm{r}$. książę Czartoryski pisał w liście do matki, że kazał wykonać gipsowe odlewy (,les plâtres”) arcydzieł obecnie znajdujących się w Rzymie oraz tych, które się tam znajdowały przed wywiezieniem ich przez Francuzów (chodziło o francuskie grabieże dzieł sztuki wynikłe z postanowień traktatu zawartego w Tolentino w 1797 r.). Realizację owego zamysłu rozpoczął od tych drugich, zamierzając stopniowo skompletować całą kolekcję. Żartem dodawał, że w ten sposób będzie prawie tak bogaty, jak miejscowe muzea, w których obecnie gipsowe kopie zajmują miejsce oryginalnych statui ${ }^{43}$.

O Rzymie pisał: „Społeczeństwo tutaj jeszcze mniej przyjemne niżeli we Florencyi, ale też za to rzeczy ciekawych w różnych gatunkach tu daleko więcej. [...] Jest tu wiele do kupowania byle tylko pieniądze starczyły”44. I dalej: „Tu się często nawijają rzeczy do kupienia za dość małe pieniądze en fait de sculpture, peinture etc. Dites moi ma chère maman w jakim guście i co byś chciała mieć, rad bym wiedział co by cię bardziej ukontentowało quant au genre, au sujet etc." $"$.

Księżna Czartoryska już wcześniej, w czerwcu 1800 r., prosiła syna, aby wystarał się dla niej o jakąś ładną statuę, niekoniecznie antyczną, byleby stwarzała pozór starożytnej (aby była „d'aperçu l'antique”). Prosiła o biust fauna lub satyra, który można by było ustawić na wsporniku (,sur une queue'), albo też lwa marmurowego, panterę lub sfinksa, „cokolwiek będzie żeby nie nadto małe, bo to na dworze ma stać"46. Czartoryski w połowie sierpnia pisał do matki z Rzymu, że wybrał tu dla niej głowę Safony, która będzie kosztowała 40 dukatów, co jest zwyczajną ceną za głowy naturalnej wielkości ${ }^{47}$. O rzeźbie tej wspominał kilkakrotnie ${ }^{48}$, ale księżna jej nie chciała, wolała biust fauna lub panterę albo sfinksa, a w ostateczności jakąś ładną wielką wazę ${ }^{49}$. Ustalenia dotyczące tego zamówienia przewijały się w korespondencji przez kilka następnych miesięcy. Książę chciał się dowiedzieć, jakiej wielkości ma być owa pantera lub sfinks, czy ma to być figura stojąca

\footnotetext{
42 Giornali di Pacetti, s. 214: „Adi primo Febraro [1801]. Hò fatto Accademico d'onore il Principe Adamo Sartorischi con acclamazione di tutti” (,con acclamazione di tutti” dodane nad wierszem).

${ }^{43}$ BCzart., rkps 6097, s. 217 (list księcia z Rzymu 17 I 1801): „J'ai fait faire les plâtres de tous les chef d'oeuvre qui existent ou qui ont existé ici avant qu'on ne les aie pris. Et d'abord j'ai commencé par ces dernieres qui sont en grand nombre, me proposant de completter à mesure la collection; de cette manière je serai presque aussi riche que les musées d'ici, qui n'ont aussi conservé que des plâtres au lieu des statues; au reste cela en tient lieu beaucoup mieux que la copie la plus parfaite".

${ }^{44}$ BCzart., rkps 6097, s. 200 (list księcia z Rzymu 8 XI 1800).

45 BCzart., rkps 6097, s. 227 (list księcia z Rzymu 28 III 1801).

${ }^{46}$ BCzart., rkps 6288, t. 1: Listy do Adama Jerzego Czartoryskiego od matki Izabeli z Flemingów Czartoryskiej z lat 1780-1800 (pisane w języku polskim i francuskim), s. 338 (list księżny z Puław 25 VI 1800): „Proszę cię mój Panie Adamie żebyś mi się wystarał o jaką statuę ładną. Ja nie chcę żeby była koniecznie antique, byle d'aperçu l'antique, chciała bym albo un buste de faune ou de Satyre qu'on puisse mettre sur une queue to jest à peu près w tym guście jak tu na papierku przyłączam. Albo lwa marmurowego, albo une Panthère, albo un Sphinx. Cokolwiek będzie żeby nie nadto małe, bo to na dworze ma stać".

${ }^{47}$ BCzart., rkps 6097, s. 182 (list księcia z Rzymu 16 VIII 1800): „Je ne sais si vous serez contente de la tête que j’ai choisie. Comme vous avez déjà plusieurs femmes j'ai pensé que vous preferiez une autre tête et j'ai commendé celui de Sapho, może ty wcale nie będziesz kontenta z tego konceptu, który będzie kosztował 40 \# qui est le prix accoutumé des têtes de grandeur naturelle; si cela n'etoit pas si long, j'auroi preferé d'attendre votre reponse avant de faire exécuter la tête".

${ }^{48}$ BCzart., rkps 6097, s. 188 (list księcia z Rzymu 30 VIII 1800), s. 190 (list z Rzymu 13 IX 1800).

${ }^{49}$ BCzart., rkps 6288, t. 1, s. 352 (list księżny z Puław 10 X 1800): ,je vous ai déjà repondue sur la tête de Sapho: ja ci za nią dziękuję, i wolę un buste de faune ou une panthère ou un Sphinx, a na reszcie un beau grand vase, ale to najmniej chyba z biedy".
} 
czy też siedząca lub leżąca (list z 22 listopada 1800) ${ }^{50}$. Księżna Czartoryska pisała w końcu lutego 1801 r., że prosi o biust fauna albo o panterę, ,jedno albo drugie dość duże, żeby na dworze mogły stać" 51 . W marcu przypominała, że rzeźba pantery powinna być duża, przynajmniej wielkości naturalnej, bo ma stać w ogrodzie ${ }^{52}$. Czartoryski jeszcze w końcu marca 1801 r. pytał matkę, czy chce mieć panterę czy też fauna lub satyra - obie czy tylko jedną z tych rzeźb, prosił, aby określiła jej wielkość, rodzaj marmuru (kolorowy czy biały) i na czym będzie ustawiona, a także czy pantera ma być leżąca czy stojąca ${ }^{53}$. $\mathrm{Z}$ dalszej korespondencji wynika, że książę ostatecznie zamówił rzeźbę pantery w Rzymie dopiero bezpośrednio przed wyjazdem z Italii, w maju $1801 \mathrm{r}^{54}$

Księżna Czartoryska prosiła też syna w końcu września 1800 r., aby postarał się dla niej o starożytny ołtarz ze świątyni Westy w Tivoli (Czartoryska pisze o „Temple de la Sibille”), który podobno znajduje się w tamtejszej oberży, gdzie służy jako stół, oberżyście bowiem „to na nic się nie przyda, a do mego kościółka byłaby [to] przedziwna rzecz" ${ }^{55}$. W połowie grudnia pisała do syna, aby wraz z wysyłanymi dla niej marmurami przysłał jej także jakaśs pamiątkę z Rzymu, z Kapitolu lub z Panteonu, jakiś kawałek gzymsu, kapitelu czy reliefu ${ }^{56}$. Przypominała też później: „Nie zapomnij o tych kamieniach, o które cię prosiłam, z różnych reszt po dawnych sławnych gmachach. Kawałki gzymsów, albo bas reliefy, albo choć i gładkie kamienie, byle z takich pamiątek, które interesować mogą" "57. Czartoryski zapewnił matkę, że wypełni jej zamówienie co do kamieni i dołączy do nich kilka interesujących pamiątek ${ }^{58}$. W końcu stycznia pisał: ,już zacząłem dla ciebie różne gruzy zbierać".

\footnotetext{
${ }^{50}$ BCzart., rkps 6097, s. 203 (list księcia z Rzymu 22 XI 1800): „Względem twojej Pantery lub Sphinxy proszę ma chère maman mi napisać jakiej ma być wielkości i czy stojąca, czy siedząca lub leżąca, ne vous impatientez pas de ces retards; lepiej to jak żeby potym zrobiwszy nie zdało się; bez tego nie mogło by być teraz posłane i choć bym stąd i wyjechał to nic nie zaszkodzi kommissowi”.

${ }^{51}$ BCzart., rkps 6288, t. 1, s. 308 (list księżny ze Lwowa 23 II 1801 - w dacie omyłkowo rok jako „1800”, dopisany później): „Dziwujesz się, że ci komisu nie daję ani na obrazy ani na statuy. Pierwsze drogie, a ja nie mam passyi decydowanej do nich; statuy tom cię prosiła o buste fauna, albo o Pantherę, jedno albo drugie dość duże, żeby na dworze mogły stać. Ale to mój kochany panie Adamie dans le cas, on cela ne servit pas trop cher. Car comme je veux finir mon temple cette année, je garde tous mes moyens pour cela, jusqu'a me refuse les plus petites fantaisies, żeby wszystkie pieniądze na to obrócić".

52 BCzart., rkps 6288, t. 2: Listy do Adama Jerzego Czartoryskiego od matki Izabeli z Flemingów Czartoryskiej z lat 1801-1815, s. 6 (list księżny ze Lwowa 19 III 1801): „Pytasz mnie, jak wielką bym chciała mieć Pantherę, ja ci na to powiem, że radabym ją mieć dużą dlatego że to na dworze będzie stało. Przynajmniej comme nature, z reszty na ciebie się spuszczam, byle nie była za małą by ją na dworze w ogrodzie postawić”.

${ }^{53}$ BCzart., rkps 6097, s. 226-227 (list księcia z Rzymu 28 III 1801): „Vous me donnés vos commissions pas d'une manière assez detaillée, je vous prie ma chère maman de me dire si vous voulés avoir la pantère ou le faune ou satir tous les deux ou une seule de ces statues; de me preciser la grandeur, de quel marbre vous le voulez de couleur ou blanc, sur quoi cela doit être placé, si la pantère doit être couchée ou debout".

${ }^{54}$ BCzart., rkps 6097, s. 234-235 (list księcia z Neapolu 28 IV 1801): „Panterę jeszcze przed wyjazdem w Rzymie zakażę, wszelkie uczynię układy aby rzeczy jak najprędzej były wysłane jak tylko morze bezpieczne będzie”.

${ }^{55}$ BCzart., rkps 6288, t. 1, s. 348 (list księżny z Puław 27 IX 1800): „Pan Stanisław [Stanisław Kostka Potocki - KMR] powiada, que a Tivoli où etoit l'ancienTemple de la Sibille qui sert de modèle au mien, il y a une auberge; que dans cette auberge il y a un aubergiste, et que cet aubergiste a chez lui l'ancien autel de ce temple, dont il se sert comme d'une table. Si cela est, tâchez de l'avoir mój Panie Adamie pour moi. Jemu to na nic się nie przyda, a do mego kościołka była by przedziwna rzecz; mógł byś mi to przysłać razem z drugimi marmurami”.

${ }^{56}$ BCzart., rkps 6288, t. 1, s. 356 (list księżny z Puław 17 XII 1800): „o toż ciebie proszę bardzo, ale bardzo, żebyś z temi marmurami co dla mnie kiedyś przyjdą, żebyś może kazał na okręt wsadzić quelques souvenirs de Rome: soit du Capitole, soit du Pantheon. Ja nie koniecznie pretenduję co wielkiego: niech będzie kawałek rogu czy kapitelu czy bas reliefu. Mój Panie Adamie proszę cię o to bardzo, vous me ferez un extrême plaisir".

${ }^{57}$ BCzart., rkps 6288, t. 2, s. 3 (list księżny ze Lwowa 18 II 1801).

${ }^{58}$ BCzart., rkps 6097, s. 215-216 (list księcia z Rzymu 9 I 1801): „Je remplirai votre commission ma chère maman au
} 
Miał wówczas już kawałek urny Scypionów i fragment granitowego obelisku ze świątyni Fortuny koło Palestriny, ale, jak uprzedzał, „to tylko początek, będzie tego długa litania, w której cała historia rzymska będzie mogła być powtórzona"; a zamierzał też przesłać matce wykaz zebranych fragmentów ${ }^{59}$.

W korespondencji Czartoryskich wielokrotnie wymieniane są „,marmury” księżny złożone u „rzeźbiarza Maximiliana”, które miały zostać wysłane z Rzymu do Puław. W końcu lipca księżna pisała do syna, aby będąc w Rzymie starał się „dobrze ułożyć komis” z Maximilianem; sarkofag i statua są zapłacone od dawna oprócz transportu, ,ale niech to nie będzie expediowane, aż jak pokój ostanie, bo by mi to wzięli, a szkoda"60. Książę w połowie sierpnia powiadomił matkę, że marmurowe dzieła, które znajdują się dla niej u rzeźbiarza Laboureura, nie będą mogły zostać wysłane w inny sposób niż morzem do Gdańska, a stamtąd dalej Wisłą. Wszystko już jest zapakowane, ale nie jest jeszcze zdecydowany co do terminu wysyłki ${ }^{61}$. W liście z 30 sierpnia pisał: „Le Sculpteur Maximilien już zapłacony, wszystko już pokończone i zapakowane, ale nie może iść inaczej jak tylko przez morze do Gdańska, i myślę tak, że lepiej i jeszcze poczekać i nie posyłać zaraz"62.

W końcu września księżna posłała synowi polecenie wydania mu także małego grobowca złożonego u Maximiliana, który dostała od Aleksandry Potockiej, żony Stanisława Potockiego: „Posyłam ci także rozkaz do wydania un petit tombeau, que mad: Stanislas m'adonné et qui est deposé chez Maximiliano"63. Czartoryski pisał miesiąc później, że mały grobowiec „du Pi...” (tu urwane) jest już w skrzyni fauna, a co do stołu oberżysty $\mathrm{z}$ Tivoli dowie się o niego i kupi, ale wątpi czy tam jest, bo będąc w Tivoli nic o nim nie słyszał ${ }^{64}$.

sujet des pierres auxquelles est joint quelque souvenir interessant; c'est ici plus que partout ailleur qu'on peut faire facilement une pareille collection".

${ }^{59}$ BCzart., rkps 6097, s. 219 (list księcia z Rzymu 24 I 1801), s. 227 (list z Rzymu 28 III 1801: „Dans peu je vous envoierai ma chère maman la note des fragments que j’ai rassemblés ici”). Księżna dziękowała synowi: „Extra jestem kontenta z ruderów co mi wybrałeś i co mi obiecujesz. Il y a long tems que je n'ai eu quelque chose qui m'aye fait plus de plaisir. Scipionów urna i obelisk i reszta co mi obiecujesz przednie są rzeczy; il y a long tems que je n'ai rien en qui m'aye fait autant plaisir” (BCzart., rkps 6288, t. 1, s. 307-308, list księżny ze Lwowa 23 II 1801), ,Za różne ułomki co mi wybrałeś i chcesz przysłać extra ci dziękuję. Cela me fait un plaisir indicible, jak dziecko się tym cieszę" (BCzart., rkps 6288, t. 2, s. 6, list księżny ze Lwowa 19 III 1801). Obiekty te zostały umieszczone przez księżnę Czartoryską w Domu Gotyckim w Puławach; por. Izabela CzArToRYska, Poczet pamiatek zachowanych w Domu Gotyckim w Puławach (Warszawa: W Drukarni Banku Polskiego, 1828), s. 10, przypis księżny przy poz. 42: „Ta pamiątka i wszystkie inne tyczące się gmachów i budowli starożytnych we Włoszech dawno wzniesionych, wzięte są z miejsc właściwych i przywiezione przez J.O. xięcia Adama Czartoryskiego"; dopiski także na s. 17 przy poz. 152 i 160. Zob też: ŻYGULSKI (Jun.), „Dzieje zbiorów puławskich”, s. 151, 205; Мікоскі, „Sztuka starożytna”, s. 210-213; ID., Najstarsze kolekcje starożytności, s. 69-76; Alina AleKSANDrowicz, Izabela Czartoryska: polskość i europejskość (Lublin: Wydawnictwo UMCS, 1998), s. 317-318.

${ }^{60}$ BCzart., rkps 6288, t. 1, s. 342 (list księżny z Puław 22 VII 1800).

${ }^{61}$ BCzart., rkps 6097, s. 183-184 (list księcia z Rzymu 16 VIII 1800): „Tous les ouvrages de marbre qui se trouvent pour vous chez le Sculpteur Laboreur ne peuvent aller que par mer à Danzig pour de là remonter la Vistule. Tout est déjà embalé, mais je suis encore indeci sur le moment où je les expedierai, je voudrois d'ailleurs que la tête de Sapho puisse aller avec".

62 BCzart., rkps 6097, s. 188 (list księcia z Rzymu 30 VIII 1800). Księżna jeszcze w lutym następnego roku pisała do syna: „Mon cher ami envoyés moi je vous prie le sarcophage et tous mes souvenirs par mer: il m’en coutervit [sic] trop de fair venus tout la par terre. Mais je vous prie d'attendre avec toute la commission qu'on fasse la Paix, car autrement cela pourrait être pris [...]. Prosze cię czekaj aż pokój będzie i morzem wszystko przyślij. Jeszcze bym chciała żebyś kazał asekurować” (BCzart., rkps 6288, t. 2, s. 3, list księżny ze Lwowa 18 II 1801).

${ }^{63}$ BCzart., rkps 6288, t. 1, s. 348 (list księżny z Puław 27 IX 1800).

${ }^{64}$ BCzart., rkps 6097, s. 199 (list księcia z Rzymu 30 X 1800): „Le petit tombeau du Pi [dalej puste miejsce - KM-R] etoit déjà dans la caisse du faune ainsi je n'ai pas même besoin de montrer l'ordre signé par $\mathrm{M}^{\mathrm{r}}$ Stanislas et quant à la table 


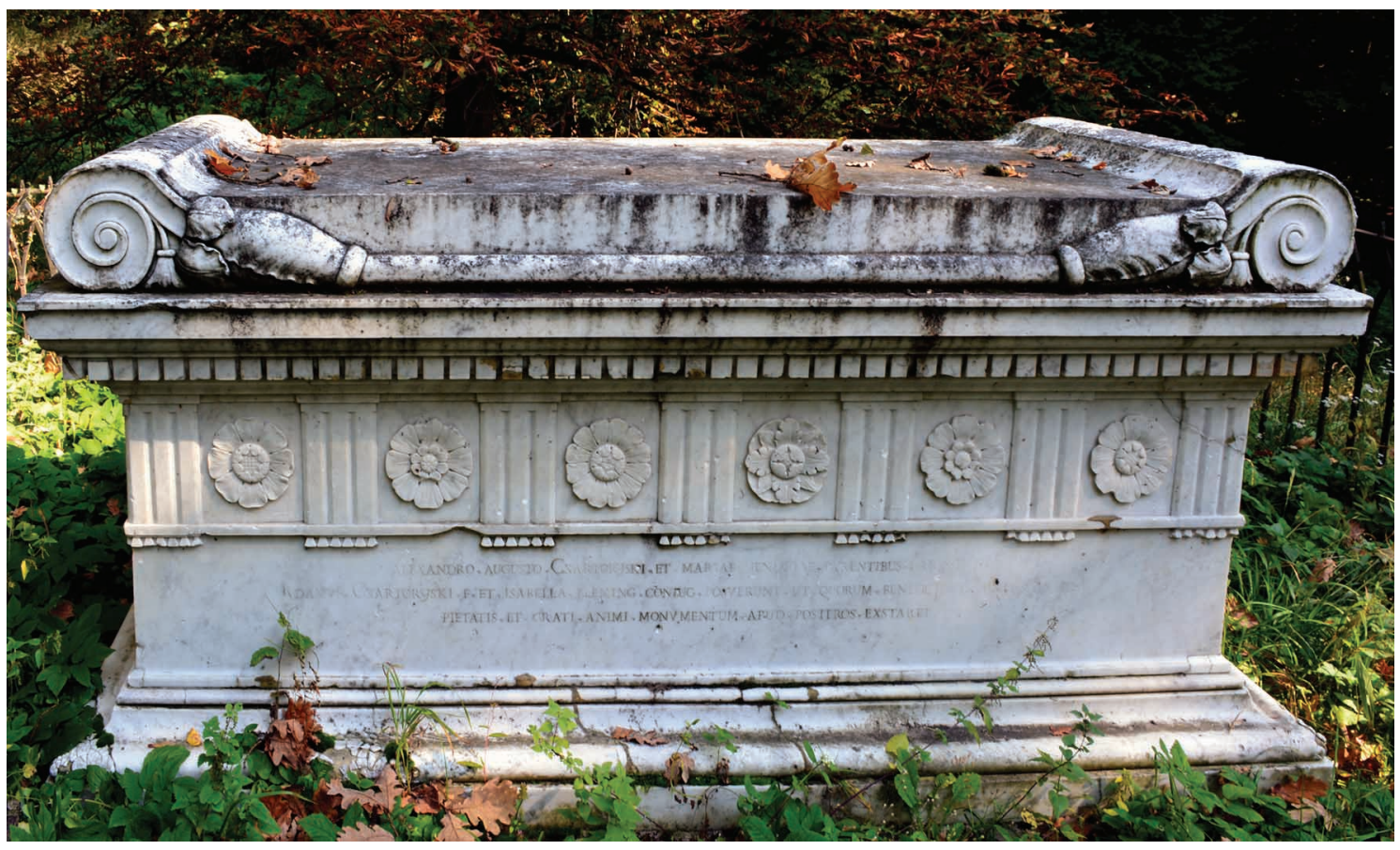

4. Francesco Massimiliano Laboureur, pomnik Augusta Czartoryskiego i jego żony Marii Zofii z Sieniawskich, marmur biały, 1797, Puławy, zespót pałacowo-parkowy. Fot. Katarzyna Mikocka-Rachubowa

Sprawa ostatecznego uregulowania należności za owe „marmury” księżny, w czym pośredniczył Stanisław Kostka Potocki, przewijała się w korespondencji Czartoryskich przez wiele miesięcy, od kwietnia 1800 do marca 1801 r. (książę sam poniósł jedynie koszta ich zapakowania, które, jak pisał, były znaczne) ${ }^{65}$. Artysta określany w korespondencji Czartoryskich jako „Maximiliano” lub „le sculpteur Laboreur” to najpewniej znany rzymski rzeźbiarz Francesco Massimiliano Laboureur (1767-1831), nazywany „Massimiliano” lub „cavaliere Massimiliano” (był bowiem kawalerem papieskiego Orderu Złotej Ostrogi) ${ }^{66}$. Powodowało to pewien zamęt w informacjach dotyczących jego dorobku, niektóre dzieła bywają bowiem odnoszone do ojca artysty, Massimiliana Laboureura (1739-1812), który był również rzeźbiarzem ${ }^{67}$. Francesco Massimiliano Laboureur, autor wielu rzeźb wysyłanych do Francji, Anglii, Niemiec i Rosji, pracował też kilkakrotnie dla polskich zleceniodawców. W 1804 r. otrzymał wiele zamówień od bawiących wówczas

de l'aubergiste de Tivoli je m'en informerai et si elle existe j'en ferai l'emplète, mais je doute que cela soit car je n'en ai rien entendu dire lorsque j'ai été à Tivoli".

${ }^{65}$ BCzart., rkps 6097, s. 165 (list księcia z Florencji 20 IV 1800), s. 188 (list księcia z Rzymu 30 VIII 1800), s. 198-199 (list księcia z Rzymu 30 X 1800), s. 202-203 (list księcia z Rzymu 22 XI 1800), s. 209 (list księcia z Rzymu 8 XII 1800); BCzart., rkps 6288, t. 1, s. 342 (list księżny z Puław 22 VII 1800), s. 348 (list księżny z Puław 27 IX 1800); BCzart., rkps 6288, t. 2, s. 6 (list księżny ze Lwowa 19 III 1801). We wzmiankach tych wymieniany jest Stanisław Kostka Potocki, który już wcześniej pośredniczył w załatwianiu spraw związanych z płatnościami za rzeźby wykonane dla księżny Czartoryskiej i ich transportem do kraju, o czym pisał w swoim pamiętniku: Archiwum Główne Akt Dawnych w Warszawie, Archiwum Gospodarcze Wilanowskie [dalej: AGAD, AGWil.], Anteriora, nr 302: [Stanisław Kostka Ротоскі], Pamiętnik Interessów samego JW. Hrabi Potockiego senatora wojewody, 1797-1812, k. 1 (wzmianka z 1 IX 1797), k. 5v (wzmianka z listopada 1797), k. 18v (wzmianka z maja 1798), k. 45v (wzmianka z 15 III 1800).

${ }^{66}$ Zob. Мiкоска-Rachuвowa, Canova, jego krag i Polacy, t. 2, s. 212-234; EAD., Rzeźba wloska w Polsce, t. 2, s. 320354 (tamże wcześniejsza literatura).

${ }^{67}$ Zob. Мiкоска-Raснuвоwa, Rzeźba wloska w Polsce, t. 2, s. 323 (tamże wcześniejsza literatura). 


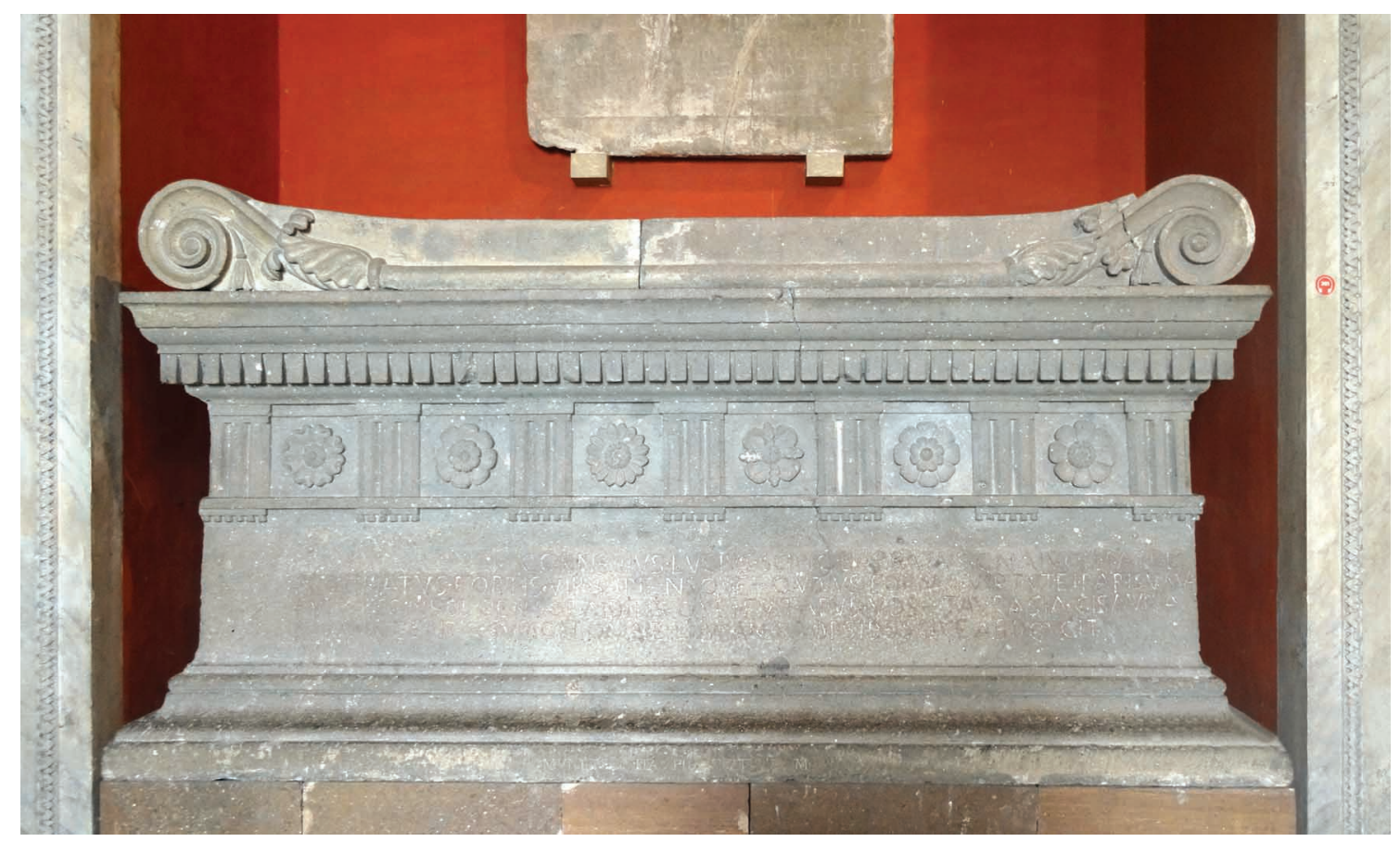

5. Sarkofag Lucjusza Korneliusza Scypiona (zwanego Barbatus), peperino, ok. 280-270 p.n.e., Rzym, Muzea Watykańskie, Museo Pio-Clementino. Fot. Katarzyna Mikocka-Rachubowa

w Rzymie Jana Feliksa i Walerii Tarnowskich, w których korespondencji określany jest także jako „Massimiliano” lub „cavaliere Massimiliano”68.

Książę Czartoryski pisał do matki w końcu marca 1801 r., że nie spodziewa się, aby jej marmury mogły zostać wysłane jeszcze w tym roku, bo sprawy z Anglią nie układają się dobrze $^{69}$. W końcu kwietnia, przed wyjazdem z Włoch, zapewniał ją, że uczyni wszystko, aby „rzeczy jak najprędzej były wysłane jak tylko morze bezpieczne będzie”70. Jednak jeszcze w początkach 1802 r. księżna prosiła mieszkającego już wówczas w Petersburgu syna, aby interweniował w sprawie marmurów z Italii, których ciagle nie ma, pomimo pokoju i braku przeszkód dla transportu ${ }^{71}$. Również w lipcu nalegała: „Proszę cię pisz [...] o moje marmury i o fragmenta coś dla mnie pozbierał. [...] cały rok zeszedł, a tu nie ma nic"72.

Transport, o który prosiła księżna, został wysłany z Rzymu dopiero późną wiosną lub latem 1802 r. Wśród licencji na wywóz dzieł sztuki poza granice Państwa Papieskiego

\footnotetext{
${ }^{68}$ Мiкocka-Rachubowa, Canova, jego krag i Polacy, t. 1, s. 113, 115-117, 131; t. 2, s. 218-229; EaD., Rzeźba wtoska w Polsce, t. 1, s. 96-99; t. 2, s. 330-342.

${ }^{69}$ BCzart., rkps 6097, s. 227 (list księcia z Rzymu 28 III 1801): „Je n'ai pas l'espoir que vos marbres puissent être envoyés par mer cette année, car les choses ne paroissent pas s'arranger avec l'Angleterre".

${ }^{70}$ BCzart., rkps 6097, s. 234-235 (list księcia z Neapolu 28 IV 1801).

${ }^{71}$ BCzart., rkps 6288, t. 2, s. $19-20$ (list księżny z 7 I 1802): ,je vous prie mon cher ami envoyés moi l'adresse de l'homme qui doit expedier mes marbres. A present que la paix est faite, je voudrais enfin jouir de tout ce que j'ai la bas depuis si longtems. [...] envoyes moi l'adresse de tous ceux que cela regarde pour que je puisse faire cette commission. Est-ce Maximiliano le sculpteur, ou un banquier! Est-ce en Rome ou allieurs. Enfin encore une fois je crue le repette des tardés pas a un'envoyer les papiers necessaires et les adresses pour venir mes marbres d'Italie"; s. 22 (list z 21 I 1802): „Envoyés moi au plus tôt ces reussignalles [?] pour les marbres d'Italie. Zmiłuj się już nie marudź i nie odkładaj. [...] ja bym chciała już Entlich mieć te marmury".

${ }^{72}$ BCzart., rkps 6288, t. 2, s. 39 (list księżny z Nieborowa 21 VII 1802).
} 


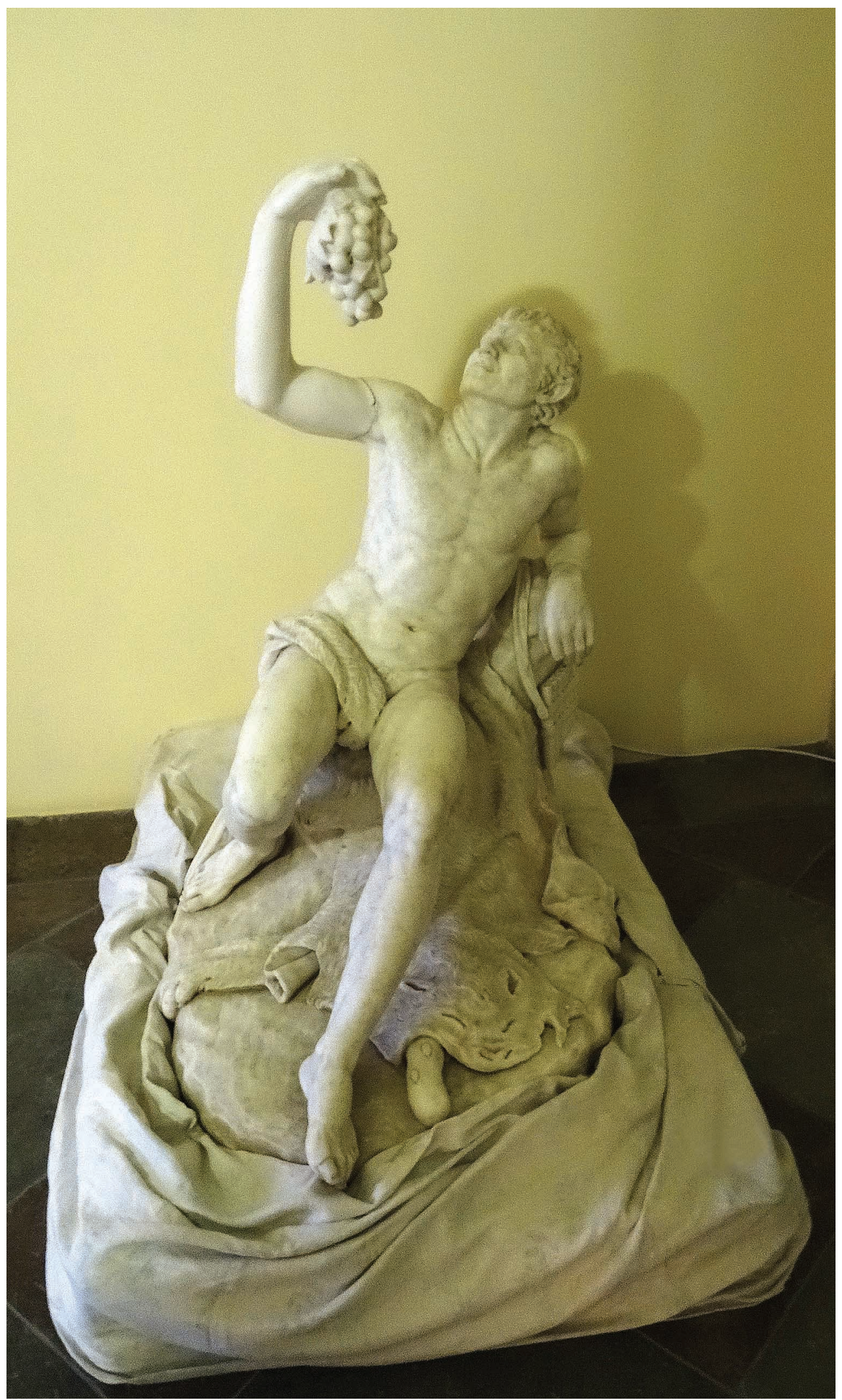

6. Faun, marmur biaty, przed 1800, Puławy, Muzeum Czartoryskich (właściciel obiektu - Instytut Uprawy, Nawożenia i Gleboznawstwa w Puławach). Fot. Katarzyna Mikocka-Rachubowa 


\section{Pijany satyr \\ (z Villa dei Papiri w Herkulanum), braz, II w. p.n.e., Neapol, Museo Archeologico Nazionale. \\ Fot. commons.wikimedia.org}

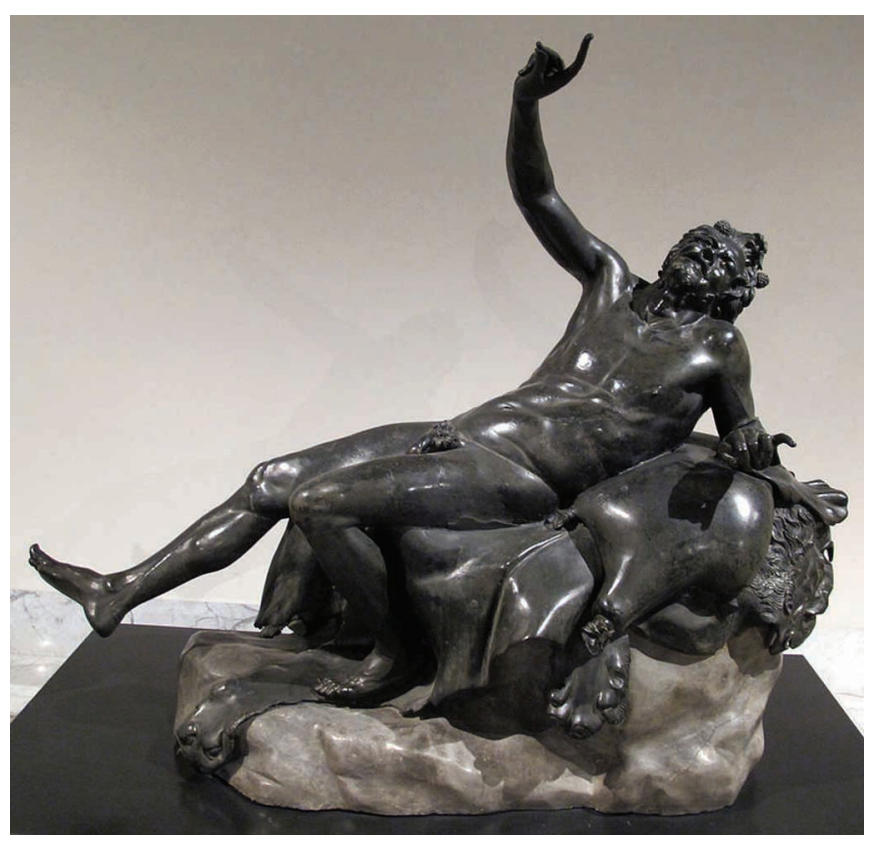

zachowała się suplika, w której opat Gioacchino Marini prosił 13 maja 1802 r. o zgodę na wysyłkę z rzymskiego portu Ripa Grande ośmiu skrzyń ze współczesnymi marmurami, które zawierają: kopię fauna, urnę Scypiona, a także fragmenty składające się na dessert oraz zbiór gipsów ,informi antichi” (według antyków); transport wyceniono na 2000 piastrów, a licencję na wysyłkę wydano 15 maja $1802 \mathrm{r}^{73}$ Nie ma wątpliwości, że był to transport realizowany na zlecenie księcia Czartoryskiego. Zaangażowany w tę wysyłkę opat Gioacchino Marini, wspominany przy okazji kontaktów księcia z Vincenzem Pacettim, był rzymskim architektem zajmującym się głównie pośrednictwem w sprzedaży dzieł sztuki zamożnym cudzoziemcom ${ }^{74}$.

\footnotetext{
${ }^{73}$ Archivio di Stato di Roma, Camerale II, Antichità e Belle Arti, busta 14: Esportazione di oggetti di antichità e belle arti, fascicolo 300 (1801-1802), karta złożona, luźna, nienumerowana: „E[minentissi]mo R[everendissi]moSig[nor]e. Desiderando L'Ab[bat]e Gioachino Marini fare imbarcare a questo Porto di Ripagrande numero otto casse marmi moderni contenenti la copia di un fauno, l'urna di Scipione, le parti componenti un Dessert ed una raccolta di gessi informi antichi. Supplica la bontà di V[ostra] E[minenza] R[everendissi]ma volersi degnare accordargliene l'oportuno permesso. [niżej innym charakterem pisma] Avendo io sottoscritto visitato lesposto giudico gli si possa accordare la richiesta Licenza e stimo tutto ciò piastre due Milla in fede questo di 13 Maggio 1802. Gio: Battista Monti Scultore ed Assessore delle Antichità. [na verso] Avendo esaminati i retroscritti marmi, e trovatili come sono descritti, e non soggetti alla dogana del 18. per 100. Non vi è difficoltà perchè S[ua] E[minenza] R[everendissi]ma il Sig[nor] Card[inale]ProCamerlengo di S[anta] Chiesa accordi la richiesta licenza. Questo di 14. Maggio 1802. A.CarloTea, Comiss[ario] delle antichità. [na verso drugiej karty] All'E[minentissi]mo e R[everendissi]mo Sig[nore] Il Sig[nor] Card[inale] Doria Pro Camerlengo di S[anta] Chiesa = Adi 15 Maggio 1802 = Attesa la Relazione del Commissario delle Antichità, ed assessore della scultura si concede la richiesta estrazione, pagando i soliti dritti doganali $=$ Card[inale] Doria Pamphilj Pro Camerlengo. Per L'Ab[bate] Gioachino Marini”.

${ }^{74}$ O Gioacchino Marinim zob. Giornale di Pacetti, według indeksu (jako „Marini, abate” i „Marini, Giovacchino”). Zob. też: Daniela Giustins, „Marini Gioacchino”, w: Architetti e ingegneri a confronto, II. L'immagine di Roma fra Clemente XIII e Pio VII, red. Elisa Debenedetti (Roma: Bonsignori, 2007), s. 161-162 (Studi sul Settecento Romano, 23); „L'arte moderna esce da Roma: regestro delle licenze d'esportazione dal 1775 al 1870”, red. Alessandra IMBELLONE, w: Roma fuori di Roma. L'esportazione dell'arte moderna da Pio VI all'Unità (1775-1870), red. Giovanna CAPITELLI, Stefano Grandesso, Carla Mazzarelli (Roma: Campisano, 2012), s. 626-726 (według indeksu); Maria Celeste Cola, „Thomas Hope and Gioacchino Marini Roman Agent of English Gentlemen”, w: London and the Emergence of a European Art Market 1780-1820, red. Susanna AverY-Quash, Christian Huemer (Los Angeles: Getty Research Institute, 2019), s. 231-244.
} 
Wymieniona w licencji „urna Scypiona” to wzmiankowany w listach Izabeli Czartoryskiej do syna marmurowy sarkofag wykonany przez Laboureura w 1797 r. Był to pomnik upamiętniający teściów księżny, Augusta Czartoryskiego i jego żonę Marię Zofię z Sieniawskich, przeznaczony do rozbudowywanej przez nią od 1796 r. rezydencji w Puławach $^{75}$ (il. 4). Jest to wierna kopia sarkofagu konsula rzymskiego Lucjusza Korneliusza Scypiona (zwanego Barbatus), wykonanego w peperino (tufie wulkanicznym) i datowanego na 280-270 r. p.n.e. (il. 5). Sarkofag ten, odkryty w 1777 r., był często kopiowany

\footnotetext{
${ }^{75}$ Sarkofag w marmurze białym carrara, ok. $122 \times 261 \times 100 \mathrm{~cm}$, Instytut Uprawy, Nawożenia i Gleboznawstwa w Puławach (stoi w parku pałacowym). Księżna Izabela Czartoryska pisała 19 III 1801 r., że już od pięciu lat na niego czeka (BCzart., rkps 6288, t. 2, s. 7): „Jeżeli by à la suite pokoju można wysłać wszystko avec securité, to bym chciała żebyś to jak najprędzej wyprawił. Il y a dejà cinq ans que j'attend[s] le sarcophage, ale jednak wolę dłużej czekać, niżeli ryzykować najmniej. Mój panie Adamie staraj się jak będzie już pokój i morze wolne żeby to ambarkować" (list księżny ze Lwowa 19 III 1801). Stanisław Kostka Potocki, który pośredniczył w załatwianiu spraw związanych z wypłatą należności Laboureurowi i wysłaniem dzieła do kraju, zanotował w pamiętniku, że 1 IX 1797 r. wypłacił rzeźbiarzowi Maximilianowi pewną kwotę za prace dla księżny (AGAD, AGWil.., Anteriora, nr 302, k. 1): „We Lwowie a 1 Septembris 1797 [...] sculptorowi Rzymskiemu Maximilianowi za roboty dla X. G. Pezzi duri 308, czyli około [fl.] 150”), a w listopadzie 1797: „November 1797. Pisałem do Maximiliana Snycerza [...] Co się tycze nadgrobka X. Wojewody [Augusta Czartoryskiego, wojewody ruskiego - KM-R], aby się z expedycją lepiej zatrzymał do pokoju między Anglią i Francją, by nie wpadł w ręce korsarzów" (ibid., k. 5v). Rzeźbiarza tego wspomniał także w maju 1798 r.: „Maius 1798 we Lwowie [...] zleciłem, ażeby zapłacił skulptorowi Maximilianowi Pezzi Duri sztuk 150”(ibid., k. 18v) i 15 III 1800 r.: „Oddałem P. Generałowey [mąż księżny Izabeli, Adam Kazimierz Czartoryski, był generałem ziem podolskich - KM-R] notatkę dla X. Adama Czartoryskiego do Florencyi dotyczącą odebrania Jey statuy będącej w Rzymie u snycerza Maximiliana, jako też nadgrobka i list do tegoż Maxymiliana przesłałem”(ibid., k. 45v). Choć sarkofagu wówczas jeszcze w pałacowym parku nie było, księżna Czartoryska wymieniła go w opisie parku w Puławach przygotowanym dla Jacques'a Delille’a: „Wychodząc ze świątyni i postępując wśród nierównego terenu, dochodzi się do wzgórza, na którym wzniosłam pomnik z białego marmuru poświęcony pamięci ojca i matki mego męża [...]. Pomnik ten wykonany został w Rzymie, na wzór i według rozmiarów grobowca Scypiona. Jest bardzo duży, pięknego stylu i z pięknego marmuru"; cyt. za: DęBICKI, Puławy (1762-1830), s. 132. W liście z 8 V 1800 r. informowała księcia Adama Czartoryskiego, że Delille zamieścił ten opis w drugiej edycji Les Jardins (BCzart., rkps 6288, t. 1, s. 331; ibid., s. 356, list księżny z 17 XII 1800). Zob. Jacques Delille, Les Jardins ou l'art d'embellir les paysages: Poëme. Nouvelle édition..., (Paris: Impr. de F.-A. Didot l'aîné, 1801), s. 10-15; Aleksandrowicz, Izabela Czartoryska, s. 57, 299-300). Sarkofag po przywiezieniu do Puław został ustawiony w pałacowym parku, na terenie tzw. Dzikiej Promenady. Przedstawiony na rysunku Jana Piotra Norblina z 1803 r. (Muzeum Książąt Czartoryskich w Krakowie, nr inw. MNK-XV-Rr. 21); zob. Ogród: forma - symbol - marzenie, kat. wyst., Zamek Królewski w Warszawie, red. Małgorzata SzAFrańsKA (Warszawa: Arx Regia, 1998), s. 352 poz. 236; zob. też: Maria SuchodolsKA, „Ikonografia Puław w twórczości Jana Piotra Norblina”, w: Pulawy, red. Stanisław LoRenTz (Warszawa: Arkady, 1962), s. 94 il. 12, s. 100-101 (Teka Konserwatorska, 5). Wymieniony w poemacie Puławy Juliana Ursyna Niemcewicza, ukończonym w początkach 1804 r.; zob. Julian Ursyn Niemcewicz, Puławy. Poemat w czterech pieśniach, wyd. Józef KallenbaCh (Brody: Nakładem i drukiem Ksieggarni Feliksa Westa, 1907), s. 45-46, w. 945-969, też s. 56. W maju 1807 r. oglądała go Waleria Tarnowska; zob. Waleria TarnowsKa, Mon Journal. Volume I, s. 326 (zapis z 15 V 1807), Biblioteka Jagiellońska w Krakowie, Przyb. 112/52. W początkach września 1824 r. sarkofag widziała Klementyna z Tańskich Hoffmanowa; zob. Klementyna z Tańskich Hoffmanowa, Wybór pism, t. 5 (Wrocław: Wilhelm Bogumił Korn, 1833), s. 86 . W 1825 r. wspominał go Antoni Amborski; zob. Antoni AmBorski, Opis Puław z przyległemi okolicami, 1829, k. 22, Biblioteka Naukowa Polskiej Akademii Umiejętności i Polskiej Akademii Nauk w Krakowie, rkps 582. Trzy lata później wzmiankowała go Sabina Grzegorzewska; zob. Sabina z Gostkowskich GrzegorzewsKa, Dziesięć dni w Puławach w roku 1828 (Kraków: Nakład wydawczyni, 1898), s. 76. Przed 1830 r. sarkofag widział także Leon Dembowski; zob. Leon DemBowski, Moje wspomnienia (Petersburg: Księgarnia K. Grendyszyńskiego, 1898), t. 1, s. 133. Po konfiskacie Puław w wyniku represji po upadku powstania listopadowego sarkofag przewieziono po $1831 \mathrm{r}$. z Puław do Podzamcza koło Maciejowic (majątku córki księżny Izabeli - Zofii z Czartoryskich Zamoyskiej) i ustawiono w parku; zob. Stanisław GoLı́́ski, Puławy: park - jego dzieje, oblicze i świat roślin, opracowano w 1924 r. (uzupetniono do roku 1932), (Puławy: Instytut Uprawy Nawożenia i Gleboznawstwa, 1988), s. 94). Do Puław sarkofag wrócił w 1947 r.; zob. Tadeusz Stefan JaRoszewsKi, „Puławy w okresie klasycyzmu”, w: Puławy, red. Stanisław LoRentz (Warszawa: Arkady, 1962), s. 80-81 (Teka Konserwatorska, 5). O sarkofagu zob. Мiкоска-Rаснивоwa, Canova, jego krag i Polacy, t. 2, s. 216-218, poz. 227; EAD., Rzeźba włoska w Polsce, t. 2, s. 326-329, poz. 247 (tamże literatura).
} 


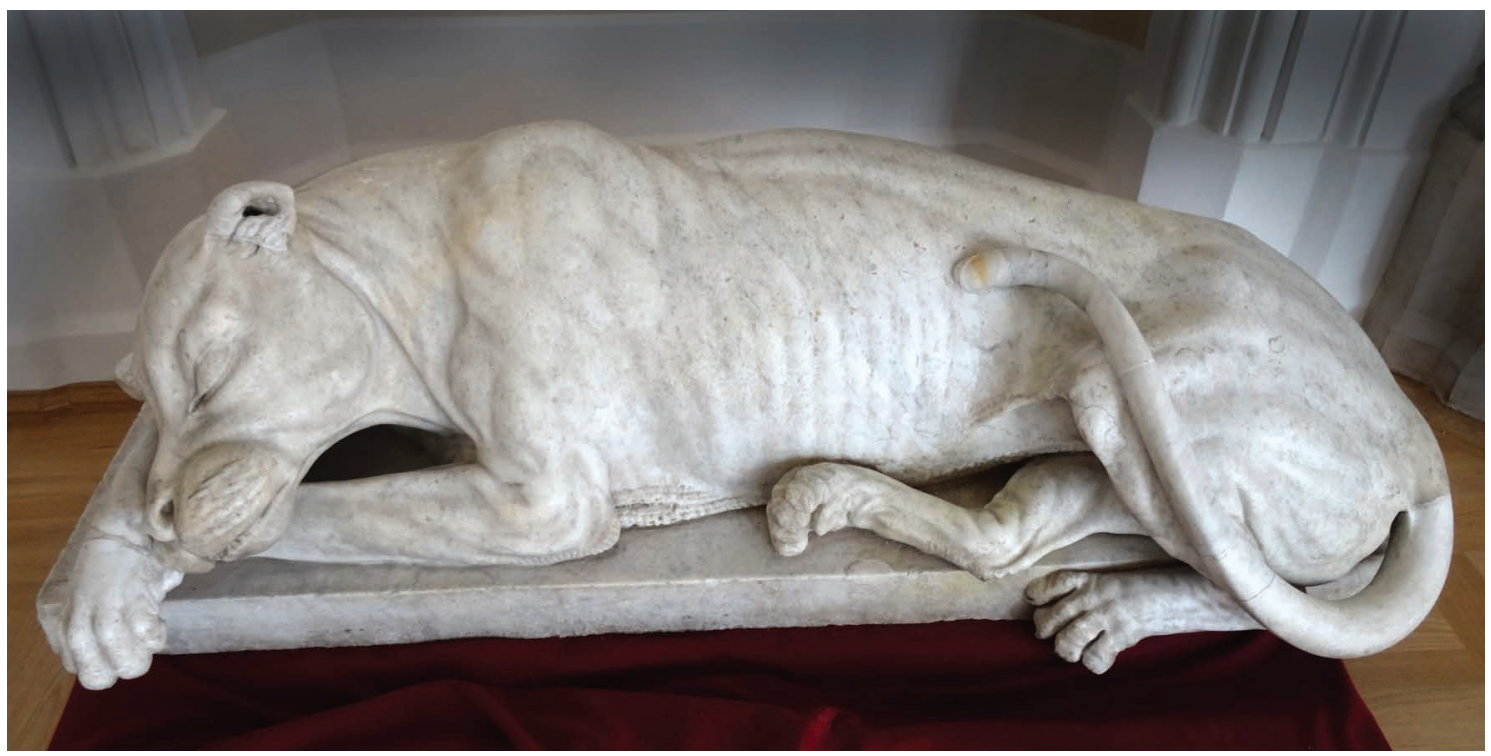

8. Pantera (Puma?), marmur biały, 1801, Puławy, Muzeum Czartoryskich (właściciel obiektu - Instytut Uprawy, Nawożenia i Gleboznawstwa w Puławach). Fot. Katarzyna Mikocka-Rachubowa

i imitowany w końcu XVIII i w XIX w. ${ }^{76} \mathrm{~W}$ transporcie znajdowała się też rzeźba fauna ${ }^{77}$ (il. 6), wyraźnie inspirowana antycznym posąiem Pijanego satyra (wys. $137 \mathrm{~cm}$ ), brązową rzymską kopią rzeźby hellenistycznej z II w. p.n.e., zdobiącą basen w centrum perystylu Villa dei Papiri w Herkulanum (il. 7). Ten odnaleziony w 1754 r. posagg często kopiowano w XVIII i XIX w. Był tam także dessert (bogata dekoracja stołu, złożona z elementów figuralnych i zdobniczych) oraz zbiór gipsowych odlewów antycznych rzeźb, niewątpliwie tych, o których książę Czartoryski pisał w listach do matki. Transport dotarł do Puław dopiero w połowie lub może wczesną jesienią 1803 r. Wynika to z listu Izabeli Czartoryskiej pisanego 6 listopada 1803 r., w którym księżna informuje syna, że jego gipsy nadeszły znacznie uszkodzone, ale zostały świetnie odrestaurowane, za wyjątkiem jednego reliefu i statui Meleagra, a ponieważ miały zostać wysłane Czartoryskiemu, księżna zastanawiała się nad ich zapakowaniem i transportem ${ }^{78}$. Marmurowy sarkofag dłuta

\footnotetext{
${ }^{76}$ Zob. Stanisław Lorentz, „Sarkofag Scipiona w Polsce”, Meander 1, nr 1 (1946), s. 36; Mikocki, „Sztuka starożytna”, s. 208.

77 Posag Fauna (Satyra), marmur biały carrara, 105×62×100 cm, Instytut Uprawy, Nawożenia i Gleboznawstwa w Puławach (dawniej w Domu Gotyckim, obecnie eksponowany w Muzeum Czartoryskich w Puławach). Rzeźba być może identyczna z owym „faunem”, o którym książę Czartoryski pisał do matki 30 X 1800, że znajdował się on w skrzyni, do której został zapakowany mały nagrobek (BCzart., rkps 6097, s. 199, zob. wyżej przypis 64). Posąg Fauna po przywiezieniu do Puław został ustawiony w niewielkim ogródku prywatnym księżny, łączącym się z jej apartamentem. Por. BCzart., rkps 6067: Izabela CzARTORYSKA, Mémoires et écrits divers, 1805-1822, s. 37: „Mon petit Jardin ou le souvenir de mes bons jours”, s. 39: „Derrière un des pillairs [piliers] de mon réduit j'ai placé un beau faune de marbre blanc sous un pin, entre des plantes odorantes. C'est l'emblème de la gayeté selon moi et j'aime à le voir entre la vue imposante du temple, le sitte melancholique de la vallées et le coup d'oeil sur cette antique Vistule qui me rapelle tant de choses". Po 1831 r. posag został przewieziony przez Zofię z Czartoryskich Zamoyską do Podzamcza koło Maciejowic i ustawiony w tamtejszym parku, przed bocznym wejściem do pałacu; zob. Golí́ski, Puławy, s. 96. Do Puław wrócił w 1947 r. Wzmiankowany w: Gerard Cıоєек, Ogrody polskie, t. 1: Przemiany treści i formy (Warszawa: Budownictwo i Architektura, 1954), s. 168; MiкоскI, Najstarsze kolekcje starożytności, s. 76; Mieczysław KsENIAK, Rezydencja ksiqżąt Czartoryskich w Puławach (Lublin: Idea Media, 1998), s. 27, 48.

${ }^{78}$ BCzart., rkps 6288, t. 2, s. 70 (list księżny z 6 XI 1803): „A propos: vos plâtres d’Italie etoient fort endomagés en arrivant.
} 
Laboureura został zatem ustawiony w parku w Puławach nie w 1801 r., jak przyjmowano dotychczas, ale najwcześniej w drugiej połowie $1803 \mathrm{r}$.

Z listu księżny wynika, że w transporcie tym nadeszła również marmurowa rzeźba pantery (il. 8), która została ustawiona w parku u wejścia do groty ${ }^{79}$. Między rzeczami przywiezionymi wówczas z Rzymu był też mały sarkofag z lawy wulkanicznej, wykonany według modelu sarkofagu „scypionowego”. Czartoryska prosi syna: „Pozwolisz żebym go wzięła, extra mi potrzebny" 80 , z czego należałoby chyba wnioskować, że nie był on identyczny z owym wspomnianym wyżej małym nagrobkiem, podarowanym księżnej przez panią Potocką. Można się jedynie domyślać, że wśród rzeźb przysłanych wówczas z Rzymu była także przechowywana od 1797 r. u „rzeźbiarza Maksymiliana”, należąca do księżny Czartoryskiej nieokreślona bliżej statua oraz „grobik mały starożytny”81.

Niespełna dwa miesiące później, 3 lipca 1802 r., opat Gioacchino Marini wystapił z supliką o zgodę na wysyłkę z Rzymu współczesnej statui w marmurze przedstawiającej Nadzieję (La Speranza), dzieła Massimiliana Laboureura, która należy do księcia Czartoryskiego; rzeźbę wyceniono na 400 piastrów, a zgodę wydano 30 lipca 1802 r. ${ }^{82}$ Posąg

Ils sont restaurés parfaitement excepté les bas reliefs et deux figures”; s. 74-75 (list księżny z 25 I 1804): „Vous voules savoir en quel etat sont vos plâtres. Ils sont presque tous reparés et restaurés parfaitement, excepté un bas relief qui etoit en poussière, et une statue de Meleagre où il manque quelques morceau. Tout le reste est très bien. J'ai quelques figures dans ma chambre, le reste est très bien placé [...]. A present il s'agit de savoir qui pourra les embaler. Arrivant de Rome ils etoit derangé parce que l'embalage etoit manqué [...]. Już bez tego tej zimy to za późno, a wieźć nie można tylko saniami”. ${ }^{79}$ Posag leżącej pantery, marmur biały carrara, $30 \times 125 \mathrm{~cm}$, Instytut Uprawy, Nawożenia i Gleboznawstwa w Puławach (dawniej w Domu Gotyckim, obecnie eksponowany w Muzeum Czartoryskich w Puławach). Księżna Czartoryska pisała o nim do syna 6 listopada 1803 r.: „Za panterę ci dziękuję, przedziwnie się wydaje przy wejściu do groty” (BCzart., rkps 6288, t. 2, s. 70). Rzeźbę po przywiezieniu do Puław ustawiono na naturalnym podwyższeniu skalnym, u wejścia do jednej z grot w zboczu wiślanej skarpy. Panterę leżącą przed grotą przedstawia rysunek Jana Piotra Norblina z 1803 r. z napisem: „Weyście do Grot ze strony Pantery. Entrée des Grottes du côté de la Panthère. 14. À Puławy en Pologne” (Muzeum Książąt Czartoryskich w Krakowie, nr inw. MNK-XV-Rr.11); zob. Ogród: forma - symbol - marzenie, s. 248, poz. 165, datowany na ok. 1803 r.; zob. też: SuchodolskA, „Ikonografia Puław”, s. 91, il. 9. W opisie Puław z 1825 r. Antoniego Amborskiego rzeźba określana jest jako „,biały zwierz morski” (Amborski, Opis Puław, k. 17v). Po upadku powstania listopadowego w $1831 \mathrm{r}$. i konfiskacie majątków Czartoryskich posąg pantery wraz z innymi rzeźbami z Puław przewieziono do Podzamcza koło Maciejowic i ustawiono w tamtejszym parku; Goliński w opisie z 1924 r. podaje, że „śpiąca puma”, uważana za zaginioną, znajduje się w parku w Podzamczu i ,postradała jeno cześć ogona, a reszta wyszła zupełnie bez szwanku" (Goliński, Puławy, s. 96-97, 110). Do Puław rzeźba wróciła w 1947 r. Zob. też: JARoszewsKI, „Puławy w okresie klasycyzmu”, s. $78-79$ (jako śpiąca pantera); MıкоскI, Najstarsze kolekcje starożytności, s. 76; KsENIAK, Rezydencja ksiażąt Czartoryskich, s. 27, 48 (jako pantera); Ogród: forma - symbol - marzenie, s. 248-249, poz. 166, autor hasła A. B. [Artur BADACH] (jako figura leżącej pumy/pantery, datowana na ok. $1800 \mathrm{r}$, eksponowana w Domu Gotyckim); Miкоска-Rachubowa, Canova, jego krag i Polacy, t. 1, s. 105, 163-164; EaD., Rzeźba włoska w Polsce, t. 1, s. 94, 127.

${ }^{80}$ BCzart., rkps 6288, t. 2, s. 70 (list księżny z 6 XI 1803): „Il y a entre d'autre chose[s] un petit sarcophage de lave sur le modèle de celui des Scipions. Pozwolisz żebym go wzięła, extra mi potrzebny”.

${ }^{81}$ Wzmiankowane przez Stanisława Kostkę Potockiego w listopadzie 1797: „Pisałem do Maximiliana Snycerza ażeby Statuę Xiężny i grobik mały starożytny expediował do Krakowa” (AGAD, AGWil., Anteriora, nr 302, k. 5v), a także 15 marca 1800 r., gdy zapisał, że wysłał do księcia Adama Czartoryskiego do Florencji, za pośrednictwem jego matki, notatkę „dotyczącą sposobu odebrania Jey statuy będącej w Rzymie u snycerza Maximiliana” (ibid., k. 45v). Księżna Czartoryska wymienia ową „statuę” w liście do syna z Puław 22 VII 1800: „Jak będziesz w Rzymie staraj się dobrze ułożyć komisse z Maximilianem. Le sarcophage et la statue, tout est payé depuis longtemps, exepté le transport"(BCzart., rkps 6288, t. 1, s. 342). Zob. też: Miкоска-Rachuвowa, Canova, jego krag i Polacy, t. 2, s. 218; EAD., Rzeźba włoska w Polsce, t. 2, s. 329. „Grobik mały starożytny” to być może ów mały nagrobek podarowany księżnej przez żonę Stanisława Kostki Potockiego, Aleksandrę Potocką, wspominany przez Czartoryską w liście do syna z 27 IX 1800 (BCzart., rkps 6288, t. 1, s. 348: „Posyłam ci także rozkaz do wydania un petit tombeau, que mad: Stanislas m'a donné et qui est deposé chez Maximiliano".

${ }^{82}$ Archivio di Stato di Roma, Camerale II, Antichità e Belle Arti, busta 14: Esportazione di oggetti di antichità e belle arti, 
personifikujący Nadzieję, którego nie udało się odnaleźć w znanym dorobku Laboureura, książę mógł zamówić nie wspominając o tym w listach do matki, a być może rzeźbę tę należałoby identyfikować z ową wspomnianą wyżej ,statuą”, czekającą u Laboureura od kilku lat na wysyłkę do Polski (choć w takim wypadku zostałaby chyba przywieziona w jednym transporcie z pozostałymi marmurami należącymi do księżny).

Po kilku latach, 5 stycznia 1805 r., Gioacchino Marini wystapił z prośbą o licencję na wywóz z Rzymu ,per la via di terra” kilku współczesnych rzeźb (,,alcune sculture moderne"), na zamówienie księcia Czartoryskiego, wycenionych na 400 skudów. Było to osiem biustów wielkości naturalnej skopiowanych z antyku, przeznaczonych do Rosji (,destinati per la Russia") ${ }^{83}$. Zgodę wydano 7 stycznia 1805 r. ${ }^{84}$

Rzeźby te, sądząc po cenie, były wykonane w marmurze. Czartoryski zamówił je z pewnością podczas pobytu w Rzymie, być może dopiero w maju 1801 r., bezpośrednio przed powrotem do Rosji, realizacja tak dużego zespołu marmurowych rzeźb zajmowała bowiem kilka lat. Niestety, podobnie jak w wypadku stojących obecnie w Puławach posągów fauna i pantery, nie dysponujemy żadnymi przesłankami, które pozwalałyby na wysunięcie hipotezy co do atrybucji owych biustów któremuś z rzymskich rzeźbiarzy.

Kilkumiesięczny pobyt księcia Czartoryskiego w Rzymie w latach 1800 i 1801 przypadł na trudne dla tego miasta czasy. Wkroczenie do Rzymu w 1796 r. francuskich wojsk i następujące po tym rządy francuskiej administracji spowodowały głęboki kryzys w społeczności tamtejszych artystów.Wojny napoleońskie dramatycznie ograniczyły sieć międzynarodowych zamówień, a liczba odwiedzających Rzym przedstawicieli europejskich

fascicolo 300 (1801-1802), karta złożona, luźna, nie numerowana: „Em[inentissim]o e R[everendissi]mo Sig[nore]. Volendo Gioacchino Marini estrarre da Roma una Statua moderna rappresentante la Speranza, e che appartiene a S[ua] A[ltezza] Il Sig[nor]e P[ri]n[ci]pe Czartorischi; supplica l'Em[inen]za V[ostr]a R[everendissi]ma ad accordergliene l'oportuna licenza. [niżej innym charakterem pisma] Avendo io sottoscritto visitato lesposto, e Lo stimo piastre quatrocento giudico gLi si possa accordare la richiesta licenza in fede questo di 3 Luglio 1802. Gio: Battista Monti Scultore ed Assessore delle Antichità [na verso] Avendo esaminata la retroscritta statua in marmo moderna opera del sig. Massimiliano Laboureur, rappresentante la Speranza, non vi è difficoltà, perchè S[ua] E[minenza] R[everendissi]ma il sig[nor] Card[inale] Pro Camerlengo di S[anta] Chiesa accordi la richiesta licenza. Questo di 28: Luglio 1802. A. Carlo Tea, Commiss[ario] delle antich[ità]. [na verso drugiej karty] A Sua Em[inen]za R[everendissi]ma Il Sig[nor] Card[inale] Doria Pro Camerl[engo] di S[anta]Chiesa. A di 30. Luglio 1802. Attesa la Relazione del Commissario delle Antichità, e dell'Assessore della Scultura, si concede la richiesta Estrazzione. S[ignor] Card[inale] Doria Pamphilj ProCamerl[engo]. Per Gioacchino Marini”. Zob. też: Miкоска-Rachuвowa, Rzeźba włoska w Polsce, t. 2, s. 329-330.

${ }^{83}$ Książę Adam Jerzy Czartoryski w latach 1804-1806 pełnił funkcję ministra spraw zagranicznych w rządzie Rosji.

${ }^{84}$ Archivio di Stato di Roma, Camerale II, Antichità e BelleArti, busta 15: Esportazione di oggetti di antichità e belle arti, fascicolo 303 (1805), karta złożona, luźna, nie numerowana: „E[minentissi]mo e R[everendissi]mo Sig[nore]. Desiderando Gioacchino Marini estrarre da Roma per la via di terra alcune sculture moderne, per commissione di S[ua] E[ccelenza] Il Sig[nore] P[rinci]pe Czartoriski, supplica V[ostra] E[minenza] R[everendissi]ma volergliene accordare la permissione. [niżej innym charakterem pisma] Avendo io sottoscritto visitato gratis Lesposto lo stimo scudi quatrocento, e giudico gli si possa accordare La richiesta Licenza in fede questo di 5. Genaro 1805. Gio: Battista Monti Scultore ed Assessore delle Antichità [na verso] Avendo esaminato le retroscritte sculture moderne, che sono 8. busti al naturale copiati dall'antico, destinati per la Russia, non vi è difficoltà, per cui S[ua] E[minenza] R[everendissi]ma il Sig[nor] Card[inale] Procamerlengo di S[anta] Chiesa non accordi la richiesta licenza. Questo di 5. gennaro 1805. A. Carlo Tea, Commiss[ario] delle antichità [niżej innym charakterem pisma] Avendo veduto le relazioni dell'Assessore della Scultura, e del Comm[issari]o delle Antichità, può Sua Em[inenz]a R[everendissi]ma il Sig[nor] Cardinal Pro:Camerlengo di S[anta] Chiesa concederne la licenza. Per il Sig[nor] Ca[valier] Antonio Canova Antonio D'Este. Dallo Studio Canova 7 del 1805 [na verso drugiej karty] No 169. A Sua Em[inen]za R[everendissi]ma Il Sig[nor] Card[inale] Doria Panfilj Pro-Camerlingo di S[anta] Chiesa. A di 7. Gennaro 1805 [niżej] Attese le Relazioni del Vice-Ispettore Generale delle Belle Arti, del Commissario delle Antichità, e dell'Assessore della Scultura, si concede la richiesta estrazione. Il Card[inale] Doria Pamphilj ProCamerlengo. Per Gioachino Marini”. Zob. też: MiкockA-Rachuвowa, Rzeźba włoska w Polsce, t. 1, s. 94, 127-128 przypis 22. 
elit znacznie spadła i nie można już było liczyć w takim stopniu jak dawniej na lukratywne zlecenia od zamożnych cudzoziemców. Wraz z okupacją Półwyspu Apenińskiego przez Napoleona zakończył się definitywnie ,złoty okres” Grand Tour, podróży odbywanej powszechnie w wyższych sferach i mającej obok aspektu czysto turystycznego walor reprezentacyjno-towarzyski. Jej głównym etapem był Rzym, gdzie rzesze peregrynantów masowo kupowały tamtejsze dzieła sztuki. Jedynie nieliczni artyści o największej renomie nie odczuwali takich ograniczeń i nadal zasypywani byli zamówieniami płynącymi z różnych stron. Rzeźbiarze, z którymi książę Czartoryski utrzymywał kontakt podczas pobytu w Rzymie, zajmowali wysoką pozycję w tamtejszym środowisku artystycznym. Zarówno Vincenzo Pacetti, wybitny kopista i dealer antyków, którego klientami byli wielcy podróżnicy i kolekcjonerzy, a dostawcami największe osobistości spośród prowadzących wykopaliska oraz właściciele wielkich kolekcji w Rzymie i okolicach, jak Francesco Massimiliano Laboureur, protegowany przez francuskich dostojników i osoby z najbliższego otoczenia Napoleona, cieszyli się sporym powodzeniem, a ich dzieła były wysyłane do wielu europejskich krajów.

Książę Adam Jerzy Czartoryski przebywał w Rzymie w misji dyplomatycznej i jego pobyt miał w założeniu inne cele niż podróże większości przedstawicieli europejskich elit, inna też była skala dokonywanych przez niego zakupów dzieł sztuki. Zainteresowany szczególnie starożytną historią i sztuką tego miasta książę podjął kilka związanych z tym inicjatyw, jak opracowanie planu antycznego Rzymu, zgromadzenie zbioru gipsowych odlewów antycznych rzeźb czy zamówienie zespołu marmurowych kopii antycznych biustów. Oglądał antyczne rzeźby w pracowni Pacettiego i był zainteresowany oferowanym mu do zakupu sławnym Faunem z kolekcji Barberinich, choć cena posagu przekraczała chyba jego finansowe możliwości. Wszystkie te poczynania i inicjatywy księcia Czartoryskiego związane ze sztuka, wynikłe z jego artystycznych zainteresowań, stanowią mało dotychczas znany aspekt młodzieńczej biografii owego wybitnego później męża stanu. 


\section{Prince Czartoryski's Purchases of Sculptures in Rome (1800-1801)}

On 12 August 1799, Prince Adam Jerzy Czartoryski (1770-1861), son of Adam Kazimierz Czartoryski and Izabela née Flemming, was appointed a representative of Tsar Paul I at the Court of King Charles Emmanuel IV of Sardinia. The King, exiled from his kingdom by Napoleon, in the autumn of that year moved into the Villa di Poggio Imperiale near Florence. Czartoryski arrived in Florence in December 1799, and stayed there until the middle of 1800 . In mid-June 1800, the King of Sardinia had to abandon his premises, and left for Rome. Prince Czartoryski followed suit, arriving in Rome in late July; he stayed in Rome until April 1801. In April, he left for Naples, where he found out about the death of Tsar Paul I, and on the orders of new Russia's Emperor Alexander I, he left Italy. Travelling via Rome, Florence, and Vienna, the Prince returned to St Petersburg in early July 1801.

Prince Czartoryski remained in Italy for almost 18 months, this having been his first stay there: the one that he dedicated some recollections to in the diaries he wrote almost half a century later. However, these feature no mentions of his contacts with Italian artists or of the artworks he purchased. Meanwhile, during the nine months he spent in Rome, Prince Czartoryski established contacts with sculptors there, and purchased sculptures. The information on the latter can be found in the correspondence with his mother Princess Izabela Czartoryska. Some fragments of the letters of the Princess to her son were published in the late $19^{\text {th }}$ century, however Czartoryski's letter written from Italy to his mother have not been publicized as yet. Mentions of the sculptures purchased by him in Italy can also be found in export licences allowing the shipment of art pieces outside the Papal States and preserved in Rome's Archivio di Stato. It was the well-known Roman sculptor Vincenzo Pacetti who wrote in his diary about the interest of Prince Czartoryski in sculptures and in their purchase. All these records allow to present Prince Czartoryski's interest in artistic questions in more detail.

During his stay in Florence from January to July 1800, Prince Czartoryski was interested in art there: he became acquainted with many artists; furthermore, he intended to create a collection of prints showing the most outstanding works of famous masters, and he himself drew pictures. Upon his arrival in Rome, in August 1800 he wrote to his mother that he was going to commission some drawings showing old Rome, while several months later he mentioned that he was making the plan of ancient Rome to which he intended to attach drawings of the ancient city. Among Prince's artrelated initiatives, it is his endeavours connected with sculpture that deserve the most interest.

Soon after his arrival in Rome, in mid-August 1800, Czartoryski became acquainted with Vincenzo Pacetti (1746-1820), a restorer, copyist, and dealer of antique sculptures. Pacetti kept a diary in which he entered events from his own activity together with the information on the personages visiting his studio. There are mentions of Prince Czartoryski in it: he visited Pacetti on several occasions viewing sculptures, paying particular attention to the statue of the Faun. Pacetti offered him the sculpture for sale, while the Prince revisited the studio to view it several times. It can be supposed that the sculpture in question was the famous Faun (Sleeping Satyr) known as the Barberini Faun, an ancient statue in marble, as of the early $17^{\text {th }}$ century property of the Barberini family. Pacetti bought it in 1798, restored, and unsuccessfully tried to sell it (the Barberinis regained the sculpture in 1804, and in 1814, it was purchased by Louis I Crown Prince of Bavaria; currently the statute at the Glyptothek, Munich). It was thanks to Pacetti's efforts that Prince Czartoryski was admitted as an honorary academic to the Academy of Saint Luke on 1 February 1801 (Pacetti was Academy's principe at the time).

In mid-January 1801, the Prince wrote to his mother that he was starting a collection of plaster casts of the sculptures in Rome, also of those taken from Rome in 1797 by the French. Already in June 1800, Princess Czartoryska had asked her son to purchase a sculpture for her: a bust of a faun or satyr, or a marble lion, panther, or a sphinx, not necessarily ancient, but of the ancient air ('d'aperçu l'antique'). Details of this request were exchanged in the correspondence over the next months. Finally, Czartoryski commissioned a sculpture of a panther in Rome in May 1801. He also intended to buy marble Sappho's head for his mother, however the Princess did not choose to have it. In late September 1800, she asked her son to try to purchase for her an ancient altar from the Temple of Vesta in Tivoli, which she wanted to place in her Puławy Temple. She also wrote asking her son to collect some minor 
relics of ancient Rome's structures for her: fragments of cornices, capitals, or reliefs; as of January 1801 the Prince amassed quite a sizeable collection of those for his mother.

In the Czartoryskis' correspondence there is frequent mention of Princess's 'marbles' awaiting at the 'sculptor Maximiliano's' for a shipment from Rome to Pulawy. The Prince wrote in August that everything had been packed, the sculptor had been paid, while the artworks were to be dispatched by sea to Gdansk, to be later transported on the Vistula, however the date for the shipment had not been decided. The artist defined as 'Maximiliano' or 'le sculpteur Laboureur' must have undoubtedly been the Roman sculptor Francesco Massimiliano Laboureur (1767-1831), called 'Massimiliano' or 'cavaliere Massimiliano'. The issue of the final payment for those 'marbles' was reiterated in the Czartoryskis' correspondence over a number of months; meanwhile, before leaving Italy, Czartoryski wrote to his mother that the marbles were most likely not to be dispatched that year. Still, in early 1802, when Czartoryski was living in St Petersburg, the Princess wrote to him asking for his intervention with respect to the shipment of the marbles from Italy. They were finally dispatched from Rome in late spring or in summer 1802. The request for the permission to dispatch eight chests with contemporary marbles valued at 2,000 piasters from the Roman port of Ripa Grande was submitted on 13 May 1802 by Abbot Gioacchino Marini (architect, dealer of art works, mentioned in the contacts of Czartoryski with Pacetti); the licence was issued on 15 May 1802. Among the sent works there was 'Scipio's urn', a marble sarcophagus executed by Laboureur in 1797, a copy of the ancient Roman sarcophagus of Consul Lucius Cornelius Scipio called Barbatus (280-270 BC), which Princess Czartoryska had commissioned as a monument to her in-laws: August Czartoryski and Maria Zofia née Sieniawska, and placed in the Puławy Palace park. The shipment also contained a marble statue of a faun: the sculpture currently at the Czartoryski Museum in Puławy, evidently inspired by the ancient statue of Drunken Satyr from the Villa of the Papyri at Herculaneum, as well as a dessert (rich sculpted table decoration), and a collection of 'informi antichi' plasters: plaster casts of ancient sculptures, unquestionably those which Prince Czartoryski had written in the letters to his mother about. The shipment which, according to Princess Czartoryska's letter, reached Puławy only in the summer or early autumn 1803, contained a marble sculpture of a panther; the latter was placed in the park at the entrance to the grotto (currently at the Czartoryski Museum in Puławy) and additionally a small sarcophagus of volcanic lava made following the model of 'Scipio's' sarcophagus.

Not fully two months later, on 3 July 1802, Abbot Gioacchino Marini submitted a request for yet another permit to export from Rome the marble statue Hope (La Speranza), work by Massimiliano Laboureur, which belonged to Prince Czartoryski; the sculpture was valued at 400 piasters, and the licence was issued on 30 July 1802. Several years later, on 5 January 1805, Abbot Marini applied for a licence to export from Rome 'per la via di terra' several contemporary sculptures ('alcune sculture moderne') commissioned by Prince Czartoryski. They were eight busts natural size, copies of ancient works, valued at 400 Italian scudos, to be sent to Russia (at the time Czartoryski's domicile was St Petersburg). The permit was issued on 7 January 1805. Czartoryski may have commissioned all those sculptures before leaving Rome, in May 1801. It is likely that on the way back from Italy he purchased two paintings: Raphael's Portrait of a Young Man and Leonardo da Vinci's Lady with an Ermine, which he presented his mother with (from 1809 both in the Gothic House in Puławy, currently Leonardo's painting at the Princes Czartoryski Museum National Museum in Cracow, while Raphael's portrait was lost in 1945).

Prince Adam Jerzy Czartoryski went to Italy on a diplomatic mission, and his stay there had other goals than that of the majority of representatives of the European elites; moreover, the scale of his purchases of art works was different than theirs. However, his endeavours at the time and art-related initiatives, resulting from his artistic interest, constitute a captivating, though to-date little known aspect of the youthful biography of the future outstanding statesman. 


\section{Bibliografia:}

Aleksandrowicz, Alina. Izabela Czartoryska: polskość i europejskość. Lublin: Wydawnictwo UMCS, 1998.

Ciołek, Gerard. Ogrody polskie. Przemiany treści i formy. Warszawa: Budownictwo i Architektura, 1954.

Cola, Maria Celeste. "Thomas Hope and Gioacchino Marini Roman Agent of English Gentlemen." W London and the Emergence of a European Art Market 1780-1820, redakcja Susanna Avery-Quash, Christian Huemer, 231-244. Los Angeles: Getty Research Institute, 2019.

Giustini, Daniela. "Marini Gioacchino." W Architetti e ingegneri a confronto, II. L'immagine di Roma fra Clemente XIII e Pio VII, redakcja Elisa Debenedetti, 161-162. Roma: Bonsignori, 2007.

Gołębiowska, Zofia. "Mecenat kulturalny Izabeli i Adama Kazimierza Czartoryskich (sztuki plastyczne, teatr, muzyka, literatura)." W Ziemiaństwo na Lubelszczyźnie. Materiały II sesji naukowej zorganizowanej w Muzeum Zamoyskich w Kozłówce 22-24 maja 2002, redakcja Róża Maliszewska, 31-70. Kozłówka: Muzeum Zamoyskich, 2003.

Haskell, Francis, i Nicholas Penny. Taste and the Antique. The Lure of Classical Sculpture 15001900. New Haven-London: Yale University Press, 1982.

Jaroszewski, Tadeusz Stefan. "Puławy w okresie klasycyzmu." W Puławy, redakcja Stanisław Lorentz, 64-86. Warszawa: Arkady, 1962.

Kseniak, Mieczysław. Rezydencja ksiażat Czartoryskich w Puławach. Lublin: Idea Media, 1998.

"L'arte moderna esce da Roma: regestro delle licenze d'esportazione dal 1775 al 1870." Redakcja Alessandra Imbellone. W Roma fuori di Roma. L'esportazione dell'arte moderna da Pio VI all'Unità (1775-1870), redakcja Giovanna Capitelli, Stefano Grandesso, Carla Mazzarelli. Roma: Campisano, 2012.

Lorentz, Stanisław. “Sarkofag Scipiona w Polsce.” Meander 1, nr 1 (1946): 34-39.

Mikocka-Rachubowa, Katarzyna. Canova, jego krag i Polacy (około 1780-1850). Warszawa: Instytut Sztuki PAN, 2001.

Mikocka-Rachubowa, Katarzyna. "Rzeźbiarz rzymski Vincenzo Pacetti i Polacy." Biuletyn Historii Sztuki 65, nr 2 (2003): 261-276.

Mikocka-Rachubowa. Katarzyna. "O Giornale Vincenza Pacettiego raz jeszcze.” Biuletyn Historii Sztuki 68, nr 1 (2006): 103-105.

Mikocka-Rachubowa, Katarzyna. Rzeźba włoska w Polsce około 1770-1830. Warszawa: Instytut Sztuki PAN, 2016.

Mikocki, Tomasz. "Sztuka starożytna w mecenacie Izabelli Czartoryskiej." Meander 38, nr 6 (1983): 205-218. 
Mikocki, Tomasz. Najstarsze kolekcje starożytności w Polsce (lata 1750-1830). Wrocław: Ossolineum, 1990.

Roma 1771-1819. I "Giornali” di Vincenzo Pacetti, redakcja Angela Cipriani et al. Pozzuoli: Naus Editoria, 2011.

Suchodolska, Maria. "Ikonografia Puław w twórczości Jana Piotra Norblina.” W Puławy, redakcja Stanisław Lorentz, 87-105. Warszawa: Arkady, 1962.

Żygulski (jun.), Zdzisław. “Dzieje zbiorów puławskich (Świątynia Sybilli i Dom Gotycki).” Rozprawy i Sprawozdania Muzeum Narodowego w Krakowie 7 (1962): 5-265. 